\title{
$\begin{array}{ll}\text { ANL/EGT-1 } & 333 \\ \text { VOLUME I } & \frac{3-27.78}{y-78}\end{array}$
}

th. 1865

\section{ENVIRONMENTAL CONTROL IMPLICATIONS OF GENERATING ELECTRIC POWER FROM COAL}

\section{Technology Status Report Volume I}

\section{ENVIRONMENTAL GONTROL- GOAL UTILIZATION PROGRAM}

\section{ARGONNE NATIONAL LABORATORY}

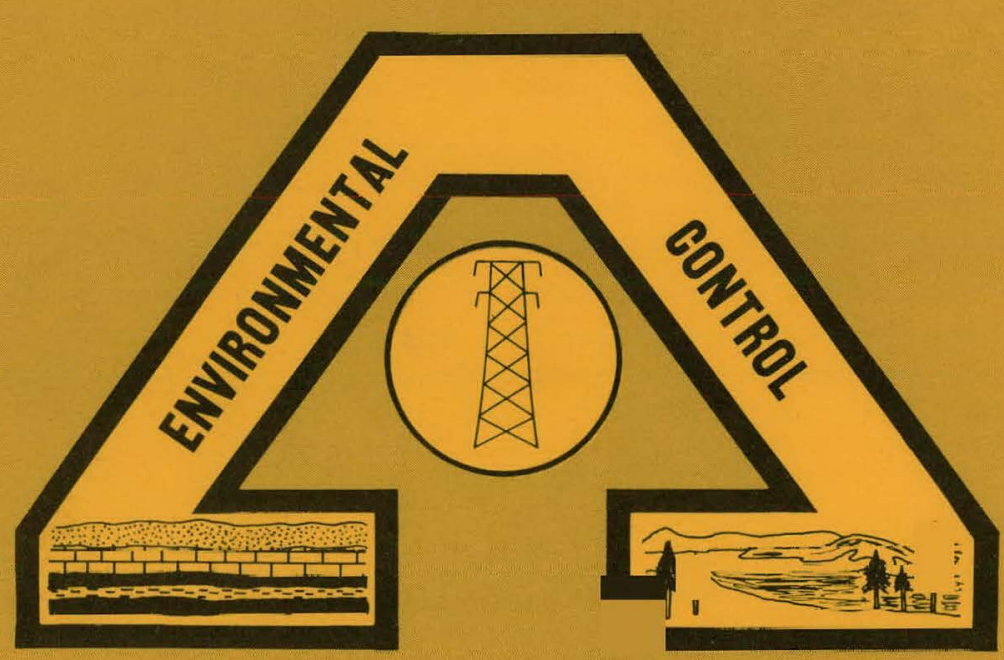




\section{DISCLAIMER}

This report was prepared as an account of work sponsored by an agency of the United States Government. Neither the United States Government nor any agency Thereof, nor any of their employees, makes any warranty, express or implied, or assumes any legal liability or responsibility for the accuracy, completeness, or usefulness of any information, apparatus, product, or process disclosed, or represents that its use would not infringe privately owned rights. Reference herein to any specific commercial product, process, or service by trade name, trademark, manufacturer, or otherwise does not necessarily constitute or imply its endorsement, recommendation, or favoring by the United States Government or any agency thereof. The views and opinions of authors expressed herein do not necessarily state or reflect those of the United States Government or any agency thereof. 


\section{DISCLAIMER}

Portions of this document may be illegible in electronic image products. Images are produced from the best available original document. 
The facilities of Argonne National Laboratory are owned by the United States Government. Under the terms of a contract (W-31-109-Eng-38) between the U. S. Energy Research and Development Administration, Argonne Universities Association and The University of Chicago, the University employs the staff and operates the Laboratory in accordance with policies and programs formulated, approved and reviewed by the Association.

\section{MEMBERS OF ARGONNE UNIVERSITIES ASSOCIATION}

The University of Arizona

Carnegie-Mellon Univer sity

Case Western Reserve University

The University of Chicago

University of Cincinnati

Illinois Institute of Technology

University of Illinois

Indiana IIniversity

Iowa State University

The University of Iowa
Kansas State University

The University of Kansas

Loyola University

Marquette University

Michigan State University

The University of Michigan

University of Minnesota

University of Missouri

Northwestern University

University of Notre Dame
The Ohio State University

Ohio University

The Pennsylvania State University

Purdue University

Saint Louis University

Southern Illinois University

The University of Texas at Austin

Washington University

Wayne State University

The University of Wisconsin

\section{NOTICE}

This report was prepared as an account of work sponsored by the United States Government. Neither the United States nor the United States Energy Research and Development Administration, nor any of their employees, nor any of their contractors, subcontractors, or their employees, makes any warranty, express or implied, or assumes any legal liability or responsibility for the accuracy, completeness or usefulness of any information, apparatus, product or process disclosed, or represents that its use would not infringe privately-owned rights. Mention of commercial products, their manufacturers, or their suppliers in this publication does not imply or connote approval or disapproval of the product by Argonne National Laboratory or the U. S. Energy Research and Development Administration.

Printed in the United States of America

Available from

National Technical Information Service

U. S. Department of Commerce 5285 Port Royal Road

Springfield, Virginia 22161

Price: Printed Copy $\$ 6.00$; Microfiche $\$ 3.00$ 
Distribution Categories:

Coal Conversion and Utilization (UC-90), plus UC-90a, -90b, $-90 e,-90 i,-90 j$

ANL/ECT-1

ARGONNE NATIONAL LABORATORY

9700 South Cass Avenue

Argonne, Illinois 60439

ENVIRONMENTAL CONTROL IMPLICATIONS

OF GENERATING ELECTRIC POWER FROM COAL

TECHNOLOGY STATUS REPORT

Volume I

December 1976

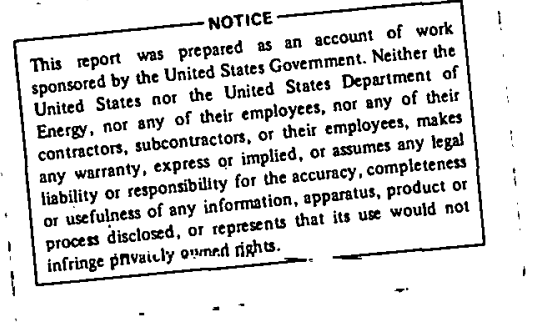

Prepared for the

Division of Environmental Control Technology

U.S. Energy Research and Development Administration

Washington, D.C. 20545 
THIS PAGE

\section{WAS INTENTIONALLY LEFT BLANK}


A continuing assessment of "Environmental Control Implications of Generating Electric Power from Coal" is being carried out for the Division of Environmental Control Technology in the ERDA Office of Environment and Safety by Argonne National Laboratory and a number of subcontractor companies. This report is the first in a series of reports to be issued under the program and represents efforts from inception of the program in March, 1976 through December, 1976. The primary emphasis in this initial report is on the characterization and evaluation of existing and near-term technologies for coal utilization. Environmental regulations and the health effects of pollutants are also reviewed.

Volume I of the report is a condensation of the technology descriptions and evaluations. It also includes recommendations for research and development activities identified by the study thus far, and an executive summary. Reference citations have been omitted from this volume in the interest of brevity and readibility.

Volume II of the report contains much more extensive and detailed technology descriptions and evaluations. The appropriate reference citations are included to identify source materials, with a list of references presented at the end of each major topic.

N. F. Sather, the Program Manager, and K. E. Wilzbach had overall responsibility for preparation of the report. Other participants in the work were:

\section{Argonne National Laboratory}
C. D. Brown
G. C. Krohm
W. I.. Buck
C. D. Livengood
R. R. Cirillo
R. T. Lundy
K. W. Costello
R. McLean
C. D. Dux
G. N. Reddy
P. S. Farber
A. E. Smith
D. Grahn
S. Vogler
H. S. Huang
S. H. Wong

A. L. Kernkamp 
Outside Consultants

C. E. Feazel

Southern Research Institute

B. S. Friedman

Private Consultant

J. Leonard

West Virginia University

H. L. Lovell

Pennyslvania State University

T. D. Wheelock

Iowa State University

R. E. Zimmerman

Paul Weir Company 
The continued and expanded use of coal for the generation of electricity in the United States is generally accepted as a certainty. This is due in large part to the oil and natural gas shortages experienced in recent years coupled with the existence of vast U.S. coal reserves. However, if this coal utilization is to take place without significant social, environmental and public health impacts, effective control technologies for power plants must be developed and implemented in order to achieve acceptable levels of airborne, waterborne, and solid waste effluents. This is the first in a series of reports evaluating such control technologies from an in-depth engineering and cost point of view. The evaluations take into account both the direct and indirect environmental and economic impacts of coal utilization, as well as other relevant factors such as reliability, the time frame for development, and the availability of required resources. Primary emphasis is placed on currently available technologies, but those expected to achieve commercial status in the near future are also analyzed. The report was prepared by the Environmental Control Technology Program at Argonne National Laboratory for the Division of Environmental Control Technology of the U.S. Energy Research and Development Administration.

Motivation for the control of power plant effluents is provided largely by deleterious health effects due to many of those substances, particularly those which are airborne. Although this is an area of intense and continuing study, the precise nature or extent of the effects has not yet been determined in most cases. There are many diffirulties related to heterogeneities in the exposed populations, quantification of received doses, measurement of biological response, and transference of animal experiment results to humans. However, enough is known for the following conclusions regarding the primary air pollutants to be made:

- Sulfur dioxide $\left(\mathrm{SO}_{2}\right)$ is an irritant for sensitive tissues, but the effect is mild for realistic dose ranges. Cor irritant effects have been noted. Carcinogenic effects may be caused by $\mathrm{SO}_{2}$ alone or through interactions with other agents. Lung clearance mechanisms may be affected.

- Nitrogen dioxide $\left(\mathrm{NO}_{2}\right)$ is the most important of the nitrogen oxides $\left(\mathrm{NO}_{\mathrm{X}}\right)$. It is a strong irritant and is also capab?.e of inhibiting lung clearaice mechanisms. Carcinogenic effects may arise from $\mathrm{NO}_{2}$ alone or through interactions with other substances. 
- Particulates cause damage through deposition in the respiratory tract. Their effects may be magnified by the actions of adsorbed irritants, such as $\mathrm{SO}_{2}$, and toxic trace elements from coal.

- Other pollutants of concern include carbon monoxide, ozone, and various hydrocarbons.

Regulations have been promulgated at various levels of government for the purpose of controlling air pollution. Some of the most important are included in the State Implementation Plans (SIPs) aimed at attainment of the National Ambient Air Quality Standards (NAAQSs) set by the EPA. Most of the SIPa rely upon emissions limitations, but other methods such ao fuel sulfur content limits and ambient air measurements are also used. A number of states specify more stringent standards than the NAAQSs, and some have regionaI variations.

All new power plants must also conform to the federal New Source Performance Standards (NSPSs), which are based on the use of the best available control technology. These represent the most stringent regulations in many areas of the country. At this time, there are NSPSs for particulates, $\mathrm{SO}_{2}$, and $\mathrm{NO}_{\mathrm{X}}$, all expressed in terms of pounds of pollutant per luillion Btu of heat input.

Compliance with the applicablo rcgulal luns has gencraily been achieved for airborne particulates and $\mathrm{NO}_{\mathrm{X}}$. However, $\mathrm{SO}_{2}$ control has been more difficult to attain, with about $43 \%$ of the coal burned for the generation of electricity in 1975 not meeting emission regulations.

Waetewater effluents from powel plants are presently regulated by numerous mechanisms. Additionally, new standards curresponding to the best practicable control technology currently available (BPCTCA) and the bcot available Lechnology economically achievable (RATEA) munt be met by July 1 , $1 y / 7$ and JuLy 1 , 1983 respectively.

In view of the compliance situation, $\mathrm{SO}_{2}$ control technology is obviously of high priority. A number of techniqueo are avallable for use, either singly or in combination. The most desirable mix will depend upon the applicable regulations, fuel availabilities, power plant type, and a number of site-specific factors. 
Many utilities have been switching to low sulfur coal, most of which is found in the western states. This coal has different characteristics from eastern and midwestern coals. Some of the salient factors are:

- Existing boilers may have to be derated for use with low sulfur coal due to its lower calorific value, higher moisture content, greater hardness, and incomplete combustion problems.

- Greater volumes of coal must be transported, stockpiled, and handled in-plant. Ash disposal systems must be enlarged.

- Particulates collection is affected since electrostatic precipitator efficiencies are lowered.

Low sulfur coal delivered costs for 1985 have been estimated for both eastern and western sources. The market boundary between coals from the two regions was found to be along a line running from Mississippi northeast through Ohio and into upper New York. Costs along that boundary were on the order of 125 cents per million Btu.

For coal higher in sulfur, there are various physical cleaning processes which can remove some of the pyritic sulfur as well as a large part of the ash. This not only lowers the sulfur content, but produces a more uniform fuel, reduces handling and transportation costs, improves combustion efficiency, and lowers ash disposal costs. Current cleaning techniques may be grouped into five levels, with the higher levels generally processing finer coal fractions and achieving greater sulfur removal with correspondingly higher costs. Constraints on sulfur reduction include the organic sulfur component (not removed by cleanling) aud technical difficulties in processing ultrafine particles.

Costs for coal cleaning to meet emissions standards were recently estimated to range from 0.5 to $2 \mathrm{mills} / \mathrm{kWh}$. For comparison, the incremental costs for lime/limestone (L/LS) flue gas desulfurization (FGD) were estimated at 4-6 mills $/ \mathrm{kWh}$. However, under some circumstances the optimum choice may be a combination of cleaning and FGD.

The feasibility of achieving efficient $\mathrm{SO}_{2}$ removal with both high and low sulfur coals through FGD has been demonstrated at a commercial (>100 MWe) scale, but concerns still exist regarding reliability, costs, and waste disposal problems of the systems. By far the most emphasis in the U.S. has been 
on wet, throwaway processes using lime or limestone. The major problems have been plugging of components due to deposition of solids and corrosion or erosion of pumps and linings. Thus far, only two large-scale systems ( $>100 \mathrm{MWe}$ ) have achieved operating reliabilities of $80 \%$ or more for a year, although some new systems have reported high reliability.

Regenerable systems producing sulfur or sulfuric acid for sale are under development, but none have been operated satisfactorily in the U.S. The double alkali process avoids some of the operating problems of L/T.S scrubbing, but the regeneration step produces the same undesirah1p sludgoc.

Current $F($ in cost information is as follows:

- Capilla1 nnşts for LE sembining un a new bUU MWe plant using $3.5 \%$ sulfur coal range from $\$ 70$ to $100 / \mathrm{kW}$. $\Lambda$ t a 0.80 load factor, incremental power costs are 4-6 mills/ kWh.

- Estimates for regenerable FGD range $\pm 25 \%$ from those for L/LS scrubbing.

- Annualized costs for retrofitted systems, are increased due to the decreased plant lifetime remaining. Low sulfur or cleaned coal may be a better choice in such a case.

- Critical cost factors include system size, fuel sulfur content, required redundancy, process energy use, and new versus retrofit installation.

Deployment of FGD is lagging hehind the F.PA estimates of sciubluers needed by 1980 ( 90,000 MWe). OnLy 17,358 MWe of capacity will be served by FGD in the East by 1980 , whereas $93 \%$ of the noncomplying utility coal was burned there in 1975 .

The control of airborne particulates has not hean a major problem ln most cases. Primarily through electrostatic precipitation (ESP), more than $90 \%$ of the fly ash produced is now collected. ESP installatinns have gencrdily performed well, and impose only a modest energy penalty on operation ( $20.3 \%$ of plant capacity for $99 \%$ collection efficiency). Total costs (based on a $68 \%$ capacity factor) are estimated to be $\sim 1 \mathrm{mill} / \mathrm{kWh}$.

However, the use of low sulfur coal produces high resistivity fly ash that is more difficult to collect than that from high sulfur coal. Larger ESP units are required, and the costs may be approximately twice those of units for high sulfur coal. Also, there is a possibility that new regulations 
may be placed on fine particulates ( $<1 \mu \mathrm{m}$ in diameter) which fall in the range of minimum operating efficiency for ESP.

To cope with these problems, fabric filters (baghouses) have been receiving attention. They are higher in maintenance costs than ESP and impose a greater energy penalty. However, they have achieved overall collection efficiencies greater than $99.8 \%$, independent of ash resistivity and largely independent of particle size.

Wet scrubbers do not appear promising for particulates removal, except perhaps for combined installations, removing both $\mathrm{SO}_{2}$ and particulates.

Nitrogen oxides $\left(\mathrm{NO}_{\mathrm{X}}\right)$ are another class of pollutants formed during combustion. They are formed by fixation of molecular nitrogen in the air at high temperatures (thermal $\mathrm{NO}_{\mathrm{X}}$ ), and by oxidation of chemically bound nitrogen in the fuel (fuel $\mathrm{NO}_{\mathrm{X}}$ ). Control of $\mathrm{NO}_{\mathrm{X}}$ has been achieved through combustion condition modifications. Current methods include:

- Low excess air (LEA) firing. $\mathrm{NO}_{\mathbf{x}}$ reductions of $20 \%$ are possible with excess air reductions of $10 \%$. There are negligible operating cost penalties and retrofit capital costs of $\$ .55 / \mathrm{kWe}$.

- Staged combustion uses both low oxygen concentrations and low flame temperatures. Reductions in $\mathrm{NO}_{\mathrm{X}}$ of up to $45 \%$ are possible at costs comparable to those for LEA firing.

- Flue gas recirculation also lowers temperatures and available oxygen but is less effective than the previous two methods and more expensive.

- New burner designs have shown potential for major $\mathrm{NO}_{\mathbf{x}}$ reductions and will prohably be the preferred approach for new units.

A number of flue gas treatment processes are under investigation for additional $\mathrm{NO}_{\mathbf{x}}$ control if it is needed. These fall into four classes, characterized by chemical absorption, physical adsorption, catalytic processes, and noncatalytic processes such as selective reduction. Costs are expected to be a least a factor of 10 higher than costs for combustion modifications.

Many of the preceding techniques for flue gas cleaning exacerbate yet another problem -- solid waste disposal. The disposal. of ash alone involves potential problems of surface and subsurface water pollution, primarily through the leaching of tuxic chemical clements from the aș. Control methods Include prevention or diversion of surface and subsurface water flows, proper 
drainage, and development of vegetative cover. However, ash does not readily support plant growth. In general, the problem can be managed by careful monitoring and employment of available technology.

The wastes from L/LS scrubbing, of ten combined with fly ash, present a more difficult problem. A new 1000-MWe plant with TS scrubber and using coal with $3 \%$ sulfur and $12 \%$ ash will produce enough waste in its first 10 years to cover one square mile to a depth of 12 feet. Also, the presence of calcium sulfite hemihydrate makes it impossible to physically dewater the. sludge to the extent required to support weight. Thus ponding of the sludge Ls ubjectionable both because of potential leaching prohlems and bccause the land is permanently withdrawn from use. Chemical fixation of sludgee using a variety of additives has achleved some success, and has produced material suitable for landfi.1. This extra step adds further to operating costs, although the extent is not yet well defined.

Two areas of advanced technology have also been investigated for this report. These are fluidized-bed combustion (FBC) and advanced coal preparation. FBC is of interest because it has the potential for good pollution control, regardless of coal type, combined with high energy cfficiency. Sume of the more important features include:

- As murh as $90 \%$ of the $\mathrm{SO}_{2}$ formed is absorbed in the bed by limestone or dolomite, forming a dry, solid waste product.

- Low combustion temperatures $\left(1500-1.700^{\circ} \mathrm{F}\right)$ produce $\mathrm{NO}_{\mathrm{X}}$ levels in the flue gas well below present limits.

- Particulates control can likely be achieved through the use of cyclones and baghouses.

- Trace element and hydrocarbon emission levels are ctill under investigation and are still highly uncertain.

- The solid discharge nf ash and opent sorleul may be disposed of by landfill, althnugh the potentially ligh $\mathrm{pH}$ of any leachate makes site-specific studies essential. Commercial uses and regeneration are being studied.

Commercial availability of large atmospheric-pressure FBC plants is expected by the mid-1980s, while pressurized FBC is projected for the mid-1990s.

Advanced coal preparation techniques may be important for the economic utilization of high sulfur coal in conventional boilers and conversion processes. New physical processes for pyrite particle removal include several based on gravity, magnetic separation, flotation, flocculation or 
agglomeration. Several advanced moisture control techniques are also under development. A number of chemically-based processes are also being investigated. Among them, the oxygen leaching, Battelle hydrothermal, and nitrogen oxides processes have the potential for both organic and pyritic sulfur removal.

During the coming year, the scope of this program will be expanded to include solvent refined coal and low Btu gasification with combined cycle combustion. The topics covered in this report will continue to be followed, and some of them will be treated in more depth than has as yet been possible. 
ABSTRACT . . . . . . . . . . . . . . . . . . . 1

1 INTRODUCTION . . . . . . . . . . . . . . . . . . . . 1

2 HEALTh EFFECTS AND REgUlatory CONSTRAints . . . . . . . . 5

2.1 HEALTH EFFECTS ANALYSIS . . . . . . . . . . . 5

2.2 SULFUR DIOXIDE ................ . . . . . 6

2.3 NITROGEN OXIDES ................... . . . . 7

2.4 PARTICULATES . . . . . . . . . . . . . . . 8

2.5 OTHER POLLUTAN'S' . . . . . . . . . . . . . . . . 8

2.6 ENVIRONMENTAL REGULATIONS . . . . . . . . . . . . 9

3 . FUEL OPTIONS . . . . . . . . . . . . . . . . . . . . . . 17

3.1 LOW SULFUR COAL . . . . . . . . . . . . . . . 17

3.2 COAL PREPARATION . . . . . . . . . . . . . . 22

3.2.1 Level One Processing . . . . . . . . . . . 24

3.2.2 Level Two Processing . . . . . . . . . . 25

3.2.3 Level Three Processing . . . . . . . . . . 25

3.2.4 Level Four Processing... . . . . . . . . 25

3.2.5 Level Five Processing . . . . . . . . . . 25

3.2.6 Pleparation Constraints and Costs........ 26

4 CONVENTIONAL COMBUSTION . . . . . . . . . . . . . . . 30

4.1 FLUE GAS DESULFURIZATTON . . . . . . . . . . . . . 31

4.2 PARTICULATE CONTROL . . . . . . . . . . . . . 38

4.3 NITROGEN OXIDES CONTROL . . . . . . . . . . . . . 42

4.4 SOLID WASTE DISPOSAL . . . . . . . . . . . . . 47

4.5 WASTEWATER CONTROL ................ 50

5 ADVANCED SYSTEMS . . . . . . . . . . . . . . . . 52

3.1 HLULDLLELD-BED COMBUSTION . . . . . . . . . . . . 52

ל.2 ADVANCED COAL PREPARATION . . . . . . . . . . . 58

6 FUTURE PROGRAM EFFORTS AND RECOMMENDATIONS . . . . . . . 61

\section{LIST OF FIGURES}

No.

$\underline{\text { Title }} \quad \underline{\text { Page }}$

3.1 Comparison of 1985 Delivered Prices of Low Sulfur Coal . . . 23 
No.

3.2 Schematic Flow Diagram of Closed Circuit Coal Preparation

Plant . . . . . . . . . . . . . . . . . . . . .

4.1 Sulfur Oxides Emissions Control for Coal-Fired Power

Plants in Eastern U.S. . . . . . . . . . . . . . . . . . .

5.1 Schematic Diagram of the Three Fluidized-Bed Combustion Systems Showing the General Energy-Conversion Cycles . . . . .

LIST OF TABLES

No.

Title

$\underline{\text { Page }}$

2.1 National Ambient Air Quality Standards . . . . . . . . .

2.2 Federal New Source Performance Standards for Coal-

Fired Power Plants . . . . . . . . . . . . . . . . .

3.1 Coal Production Costs for Marginal Mines in 1985 . . . . . . . 21

3.2 Low Sulfur Coal Price Premiums . . . . . . . . . . . . . 21

3.3 Enhancement of Coal Quality by Beneficiation . . . . . . . 28

4.1 Number and Total MWe of FGD Systems . . . . . . . . . . 33

4.2 Summary of Combustion Modification Techniques for

Control of $\mathrm{NO}_{\mathrm{x}}$ Emissions from Coal-Fired Utility Boilers . . . 44

4.3 Snmparison of Typical Sludge Dewatering Properties . . . . . 48 
ENVIRONMENTAL CONTROL IMPLICATIONS

OF GENERATING ELECTRIC PONER FROM COAL

ABSTRACT

This is the first in a series of reports evaluating environmental control technologies applicable to the coal-toelectricity process. The technologies are described and evaluated from an engineering and cost perspective based upon the best available information obtained from utility experience and development work in progress. Environmental control regulations and the health effects of pollutants are also reviewed.

Emphasis is placed primarily upon technologies that are now in use. For $\mathrm{SO}_{2}$ control, these include the use of low sulfur coal, cleaned coal, or flue-gas desulfurization systems. Electrostatic precipitators and fabric filters used for the control of particulate matter are analyzed, and combustion modifications for $\mathrm{NO}_{\mathrm{x}}$ control are described. In each area, advanced technologies still in the development stage are described briefly and evaluated on the basis of current knowledge.

Fluidized bed-combustion (FBC) is a near-term technology that is discussed extensively in the report. The potential for control of $\mathrm{SO}_{2}$ and $\mathrm{NO}_{\mathrm{X}}$ emissions by use of $\mathrm{FBC}$ is analyzed, as are the resulting solid waste disposal problems, cost estimates, and its potential applicability to electric utility systems.

The report is divided into two volumes. Volume II presents the detailed technology analyses complete with reference citations. This same material is given in condensed form in Volume I, although the references are omitted. A brief executive summary is also given in Volume $I$.

\section{INTRODUCTION}

The realities of the world's limited energy resources have been brought home forcibly to most Americans through shortages and rising prices. As one result, it has become increasingly clear that the United States must make more use of its vast coal resources, particularly for the generation of electricity. At the same time, it is obvious that exploitation of these resources can result in significant sncial, environmental, and health impacts if not properly controlled. Thus, the subject of this report, Environmental Control Implications of Generating Electric Power from Coal, has been receiving 
increased emphasis in many quarters. Most of this attention has been centered on the reduction of airborne particulate and sulfur oxide levels, but nitrogen oxide, trace element, and wastewater controls are becoming increasingly important.

A number of pollution control techniques for coal combustion are already available to the utility industry. These include the use of low sulfur coal, coal cleaning, and flue gas scrubbing for sulfur dioxide $\left(\mathrm{SO}_{2}\right)$ control; modification of combustion conditions for nitrogen oxides ( $\mathrm{NO}_{\mathrm{X}}$ ) control; and electrostatic precipitators and fabric filters for particulates control. Other promising technologies that are sti1.1 under development Include advanced coal preparation, solvent refining of coal, fluidized-bed combustion, and coal gastejcation with combined cycle combustion.

As a leading agency in the identification, support, and direction of research and development efforts, the Energy Research and Development Administration (ERDA) has a responsibility to review the status of environmental control technologies and to develop independent positions on their technical and economic feasibilities. To provide assistance in that task, ERDA's Division of Environmental Control Technology has sponsored a technology evaluation program at Argonne National Laboratory (ANL) since March, 1976. This program will produce a series of reports, of which this is the first, concentrating on evaluating control technologies for coal-to-electricity processes from an in-depth engineering and cost point of view.

The purpose of this report is to provide an assessment of the status of available and near-term technologies, and a preliminary evaluation of their potential for meeting environmental protection requirements in a costeffective manner. The available information on all of the environmental control issues associated with each technology is discussed and areas where information is lacking are identified. However, the intention is not to present a detailed description of each technology nor comprehensive analyses of their relative strengths and weaknesses.

Extensive cumpararive evaluations of the control technologies are planned for future reports in the series. It is intended that these evaluations be based on information obtained from all relevant technology work in progress, and that they be kept current as new information becomes available. Such comparative assessments can be expected to be of considerable value in 
planning development and demonstration programs, and in the selection of control systems for new power plants. Also there is apparently no other program that provides for a continuing effort to maintain a current file of information on control technologies for coal-to-electricity processes, as this program does. Because of this, it should be possible to follow progress in technology development work and trends in overall performance of control systems, and to anticipate more readily the effects of changes in emission regulations on control technology requirements.

The performance evaluations of control system options are to take into account both direct and indirect environmental and economic impacts of coal utilization. Direct impacts include emission of atmospheric pollutants, such as particulates, sulfur oxides, nitrogen oxides, hydrocarbons, and the trace elements in coal; pollutants in process wastewater, including polyaromatic hydrocarbons and trace metals; groundwater contamination by infiltration of pollutants from landfill burial of waste ash, coal fines, and scrubber sludge; and the use of resources, including both land and water. Indirect impacts include pollutant emissions from the production of process materials, such as limestone used in scrubbers and fluidized-bed combustion units, and from the production of steam, electricity, and other utilities used to operate the process or its control systems. The evaluations are to be made in the context of existing and anticipated emissions regulations for coal-fired power plants, and thus regulatory developments are being monitored. Proposed regulations will be appraised in the light of the cost penalties that they impose on the electric utility sector, combined with information about the health and ecological effects produced by environmental disturbances from power plants. Thus, the program also includes monitoring of investigations into health and ecological effects for all pollutants from each technology.

In addition to environmental impacts, the evaluations will involve a uumber of other factors affecting the potcntial for utilization of the technologies. These factors include the time frame for availability of demonstrated technology, capital and operating costs, overall energy efficiency, operating reliability, adaptability of existing facilities for retrofit or modifications, and potential for improved control efficiency. Consideration is also to be given to the availability of needed hardware, manpower, materials, and transportation facilities. 
Evaluations of the kind to be undertaken in this program will necessarily generate large amounts of information. Hence, a significant part of the program effort must be devoted to developing a systematic methodology for organizing the information and reducing it to a manageable form for making overall comparative assessments. This effort has already begun; the methodology that results will be described in detail in subsequent reports.

The following sections summarize the information compiled in the project up to the present time. In order to provide perspective for the technology discussions, a section on pollutant health effects and the regulations promulgated to mitigate those effects is given first. Next, currently available fuel, combustion, and post-combustion control options are described, followed by material on certain advanced techniques expected to beçome commercially available in the near future. Finally, expansions of the program scope in the coming year are described, and the more important research and development needs identified thus far are given. 


\section{HEALTH EFFECTS AND REGULATORY CONSTRAINTS}

Coal is chemically an extremely complex and highly variable material. As a result, the products of coal combustion contain a wide range of elements and chemical compounds, many of which have been identified as potentially deletrious to health. This fact is the primary motivation behind the search for improved environmental control technologies and the formulation of increasing numbers of environmental regulations. Therefore, both pollutant health effects and currently applicable regulations have been reviewed as part of this study.

\subsection{HEALTH EFFECTS ANALYSIS}

Health effects analysis is basically a matter of determining the biological response to measured dosages. This apparently simple task is complicated by the inevitable heterogeneities in the exposed population coupled with variations in individual exposure histories. For example, there are some individuals who always have severe short-term reactions to any increased level of a contaminant. Young children, the aged, and the infirm are generally more sensitive to the impact of increased concentrations of respiratory irritants and other poisons.

Determining the received dose for air pollutants is complicated by the need to model complex transport mechanisms and by the varied physical forms of the effluents. Oxides of carbon, sulfur, and nitrogen are present as gases; volatile organics and Inorganics exist as vapors; particulates are abundant and distributed over a wide range of particle sizes. The degree of deposition in sensitive areas and the residence time are dictated to a great extent by the physical forms of the pollutant. For example, respirable-size particles (0.01-1 $\mu \mathrm{m}$ in diameter) are able to pass the upper respiratory clearance mechanisms and enter the lower respiratory areas, remaining there for extended periods of time. Because they can absorb $\mathrm{SO}_{2}$ and other irritant gases and vapors, these particles magnify their effect by hol.ding high concentrations of these irritants in close proximity to sensitive tissues for protracted periods of time.

The measurement of biological response to a dose ts difficult bccause the distinction between good health and poor health is not sharp. Mortality is the index most commonly used because it is most easily measured. More 
useful but less available measures include the incidence and prevalence of disease. However, even when the effects are well described, the doseresponse relationship may be obscure due to uncertainties in exposure conditions or the synergistic effect of several stressors.

A major source of health effects data is animal experimentation which can be carried out under controlled laboratory conditions. There are, however, substantial uncertainties related to interspecies variations, and the data are not always directly applicable to humans. Thus, there remain many uncertainties in the prediction of pollutant health effects, particularly those for which chronic, low-level exposures over periods of many yearo are requirted.

Nevertheless, a great deal of information has been assembled on the known or suspected effects of the major components of air pollution resulting from coal combustion. These effects generally fall in one or more of the following categories: irritation, direct toxicity, carcinogenesis, lung clearance difficulties, and respiratory disease. In the following discussion, effects attributed to specific atmospheric pollutants are described.

\subsection{SULFUR DIOXIDE}

Sulfur dioxide $\left(\mathrm{SO}_{2}\right)$ was one of the earliest suspected toxic agents in alr pollution and has therefore been studied extensively. In high ronipntras. tions it is largely absorbed in the upper respiratory tract, but at low concentrations most of what is inhaled reaches the terminal bronchioles and alveu11. Thus, the effective dose is not a linear function of concentration. At concentrations which might be expected in areas of heavy coal utilization ( $735 \mu g / \mathrm{m}^{3}$ ), $3 \mathrm{O}_{2}$ LII the pure state has not been shown to produce serious direct effects.

Huwever, the potential does exist for irritation of sensitive tissues. Such irritation can stimulate an inflammatory reaction which, although basically a defensive response, may have a deleterious effect if too wide an area is involved. Realistic levels of $\mathrm{SO}_{2}$ appear to cause a slight vasoconstriction lasting about 10-20 minutes in a previously unexposed subject, accompanied by a measurable reduction in lung elasticity lasting somewhat longer. Exposures lasting several days may cause slight changes in lung 
capacity, pulmonary resistance, enzyme levels, and blood chemistry. In general, the irritant effect is mild for realistic dose ranges and tends to decrease with habituation.

Co-irritant effects have been observed in several cases. Prior exposure to $\mathrm{SO}_{2}$ seems to increase the irritation resulting from ozone $\left(\mathrm{O}_{3}\right)$ and histamine. Conversely, a subject strongly habituated to $\mathrm{SO}_{2}$ does not react as strongly to nitrogen dioxide $\left(\mathrm{NO}_{2}\right)$ as one without such prior exposure.

Carcinogenesis is one of the more difficult pollutant effects to quantify since a long latent period may elapse before tumors develop. $\mathrm{SO}_{2}$ has

a potential for long-term carcinogenic effects through production of the $\mathrm{SO}_{2}^{-}$ radical within cells. This is a relatively long-lived species with an affinity for breaking disulfide bonds and possibly causing gene mutations. The presence of $\mathrm{SO}_{2}$ may also facilitate carcinogenesis by other agents such as benz(a) pyrene.

The presence of $\mathrm{SO}_{2}$ may also enhance the effects of particulates by suppressing lung clearing actions. Acute high-level doses suppress the activity of ciliated cells in the bronchial passages, while chronic low-level doses thicken the mucus layer over the cilia.

\subsection{NITROGEN OXIDES}

Another pollutant which has recently been receiving greatly increased attention is the family of nitrogen oxides $\left(\mathrm{NO}_{\mathrm{x}}\right)$. The two most important species are nitric oxide (NO) and $\mathrm{NO}_{2}$. However, $\mathrm{NO}$ oxidizes rapidly to $\mathrm{NO}_{2}$ so that the latter is the species most commonly found in the atmosphere.

Strong irritation is the most noticeable effect of $\mathrm{NO}_{2}$ exposure. Human experiments at moderate levels have shown evidence of inflammation, although the effects seem to be delayed several hours after the onset of exposure. Chronic exposures have produced irreversible emphysema-like lesions in experimental animals. A habituation effect has been noted, as with $\mathrm{SO}_{2}$.

Carcinogenic effects arise from the formation in aqueous solution of the nitrite ion ( $\mathrm{NO}_{2}^{-}$), which in turn may contribute to formation of nitrosamines. As in the case of $\mathrm{SO}_{2}$, co-carcinogenic effects with benz(a)pyrene have been observed. 
Another similarity to $\mathrm{SO}_{2}$ occurs in lung-clearance effects, since $\mathrm{NO}_{2}$ also suppresses ciliary action in the bronchial passages.

\subsection{PARTICULATES}

Particulates form a third component of air pollution that has received extensive attention. These products tend to have diameters in the 0.01-10 $\mu \mathrm{m}$ range, which places them directly in the size range for respirable particles. Deleterious health effects may be created by the action of the particles themselves or by adsorbed gases and vapors carried by the particles to the point of deposition.

Particle size is a strong determining factor in several health effects. Those particles less than about $0.01 \mu \mathrm{m}$ in diameter behave like gases and are generally not deposited at all. Particles with diameters between 0.01 and $1 \mu \mathrm{m}$ deposit primarily in the alveolar or pulmonary region, while larger particles tend to deposit in the nasopharengeal and tracheobroncial regions. Chemical species contained in the particles also vary with size, with small particles generally being more toxic than large ones.

As noted previously, particulates may magnify the irritating effects of vapors and gases, such as $\mathrm{SO}_{2}$, by holding high concentrations of irritant in close proximity to sensitive tissues for protracted periods. The sulfate ion, which is often associated with small particles, appears to be a more potent irritant than any of the others discussed here. This is probably due to the very strong acid $\left(\mathrm{H}_{2} \mathrm{SO}_{4}\right)$ which it forms.

Trace elements from the coal may also be carried by particulates. Nickel, chromium, beryllium, and arsenic have been implicated as carcinogens. The known carcinogen benz(a)pyrene mentioned previously may be found in organic particulates. Direct disruption of cellular activity may be caused by the highly toxic elements lead, tellerium, mercury, arsenic, selenium, cadmium, nickel, chromium, and vanadium. Particles containing silica may induce various forms of fibrotic lung disease.

\subsection{OTHER POLLUTANTS}

Several other components of air pollution have been recognized as having potentially harmful effects. These include carbon monoxide (CO), ozone, and hydrocarbons. 
Co is best known for its hemoglobin affinity that results in the formation of carboxyhemoglobin ( $\mathrm{COHb}$ ). At $\mathrm{COHb}$ levels above $1.3 \%$ in the blood for over eight hours, persons with stable coronary artery disease may note increased frequency and duration of symptoms. Effects at lower levels among healthy persons are not well defined.

Ozone is one of the stronger gaseous irritants. It also has been shown to be carcinogenic in certain strains of mice and to cause premature aging in some animals.

Hydrocarbon products of combustion are many and varied. Among them, formaldehyde and acrolein are recognized as irritants. Irritant reactions may be observed in the 1-3 ppm concentration range. Carcinogenic effects appear related to the polycyclic compounds such as those derived from the benz(a)anthracene skeleton.

\subsection{ENVIRONMENTAL REGULATIONS}

At this point, it is appropriate to discuss some of the environmental regulations that have been formulated to guard against the health effects described above. Coal-fired power plants have been the subject of much of this regulation because of their potential for significant environmental impacts. In particular, air quality, has received extensive regulatory attention, although water quality is receiving increased emphasis.

The air quality management process in the U.S. relies on a multifaceted approach as prescribed in the Clean Air Act of 1970. There are basically five mechanisms for the control of air pollution.

1. National Ambient Air Quality Standards (NAAQSs), which are to be attained on a regional basis through State Implementation Plans (SIPs) (Section 109 and 110).

2. Standards of Performance for New Stationary Sources, which reflect the degree of emission limitation achievable through the application of the best system of emission reduction that has been adequately demonstrated, taking Into account the cost of achieving such reduction (Section 111).

3. National Emissions Standards for Hazardous Air Pollutants (NESHAP) for stationary source control of pollutants that may cause serious health effects (Section.112). 
4. Emission Standards for Moving Sources, whịch are required by the Clean Air Act to reduce mobile source emissions at least below a given level (Sections 202, 211, and 231).

5. Abatement by Means of Conference (Section 115) and Emergency Powers (Section 303), which are lesser-used options.

The most significant effects of these regulatory programs on coal-fired power plants, to date, have come from the first two mechanisms.

Under the ambient air quality standards approach, the federal government, through the Environmental Protection Agency (EPA), is charged with the responsibility of reviewing the potential health and welfare impacts of various pollutants, developing criteria documents outlining these impacts, and setting National Ambient Air Quality Standards (NAAQSs). To date, the EPA has promulgated NAAQSs for six pollutants, often referred to as criteria pollutants because each has an associated criteria document prepared for it. that outlines the justification for the standard. The standards are listed in Table 2.1.

The distinction between primary and secondary standards for particulates and $\mathrm{SO}_{2}$ was made to account for differences in pollutant effects. Primary standards are designed to protect public health, while secondary standards are designed to protect public welfare (e.g., materials damage, vegetation and animal damage, etc.). Increasing emphasis will be placed on secondary standards attainment as more of the Air Quality Control Regions (AQCRs) are brought into compliance with the primary standards.

Once a NAAQS has been set, each state is charged with the responsibility of developing a State Implementation Plan (SIP) that describes what steps will be taken to attain the standards. In the course of developing its SIP, each state has the option of adopting ambient standards of its own. Nearly all of the states have adopted standards for total suspended particulates (TSP) and $\mathrm{SO}_{2}$, but over a quarter have not yet adopted $\mathrm{NO}_{2}$ standards. In most cases, the states have simply adopted the NAAQS. However, about one-quarter of the states specify averaging times different from those in the NAAQS, and five states show regional variations in their standards.

In addition, 13 states have particulate standards more stringent than the NAAQS in all or part of the state. Thirty-six states have $\mathrm{SO}_{2}$ standards more stringent than the NAAQS, although 20 of those have values that are the 
Table 2.1 Natịonal Ambient Air Quality Standards

\begin{tabular}{|c|c|c|c|c|c|c|}
\hline \multirow[b]{2}{*}{ Pollutant } & \multicolumn{6}{|c|}{$\begin{array}{c}\text { Concentrations in } \mu \mathrm{g} / \mathrm{m}^{3} \\
\text { Averaging Time }\end{array}$} \\
\hline & 1-hr & $3-\mathrm{hr}$ & $8-h r$ & $24-\mathrm{hr}$ & $1-y$ & \\
\hline \multicolumn{7}{|l|}{ Particulates } \\
\hline $\begin{array}{l}\text { Primary } \\
\text { Secondary }\end{array}$ & & & & $\begin{array}{l}260 \\
150\end{array}$ & $60^{75}$ & $\begin{array}{l}(G)^{b} \\
(G)\end{array}$ \\
\hline \multicolumn{7}{|l|}{$\mathrm{SO}_{2}$. } \\
\hline $\begin{array}{l}\text { Primary } \\
\text { Secondary }\end{array}$ & & 1300 & & 365 & 80 & $(A)^{c}$ \\
\hline $\mathrm{CO}$ & $40^{e}$ & & $10^{e}$ & & & \\
\hline Hydrocarbons & & $160^{f}$ & & & & \\
\hline Oxidants & 160 & & & & & \\
\hline $\mathrm{NO}_{2}$ & & & & & 100 & (A) \\
\hline
\end{tabular}

all averages less than 1 year are not to be exceeded more than once per year.

${ }^{b}$ (G) Geometric average.

${ }^{L}$ (A) Arithmetic average.

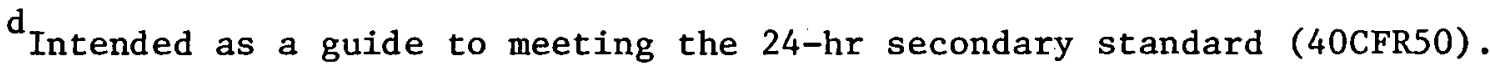

${ }^{e}$ Co concentrations measured in $\mathrm{mg} / \mathrm{m}^{3}$.

$\mathrm{f}_{6} \mathrm{a}$.m. to $9 \mathrm{a.m}$. only. The hydrocarion standard is intended as a guide to achieving the oxidant standard. 
same as the old federal secondary standards which have since been rescinded. None of the states appear to be actively pursuing the attainment of those old standards.

The ambient standards have been subject to much debate and criticism. Most recently, several groups have argued that the epidemiological studies used to develop allowable $\mathrm{SO}_{2}$ levels actually indicate that the standards should be reduced. The National Air Pollution Criteria Advisory Committee has recommended that EPA review all criteria documents for possible revision. However, any revision of existing standards will be several years away, if it occurs at all. On the other hand, there is a good possibility that additional NAAQSs will be promulgated. For example, d lead slaulald is presently under development by the EPA.

In order to attain the NAAQSs, most states have relled upon setting emission limits on the sources contributing to the air quality problems. A principal point of contention has been the link between emission rate and air quality. In most cases, this link has been made through dispersion modeling using a Gaussian plume formulation, and some arguments have centered on the validity of this approach. Other controversies have revolved about the choice of example region involved and the economlc reasonableness of the resulting regulations.

Nevertheless, 45 out of the 48 states considered here, as well as the District of Columbia, rely for particulate control on emission linits expressed in pounds of particulates per million Btu of heat input. Other mechanisms used in a few cases include grain loading, pounds of part1culaces per 1000 pounds of exhaust gas, pounds per hour, and ground level concentrations.

For sulfur oxide control, the most widely used mechanism is again the pounds of pollutant per million Btu of heat input. Th1rcy-three stales use il in their regulations with 19 using it exculsively. Eighteen states use fuel sulfur content regulations with nine relying on this mechanism alone. Six states use neither mechan1sm, relying instead on air quality mcasurcments, stack gas concentrations, or pounds per hour controls.

The fuel sulfur content regulations are in general the most constricting since they do not allow for stack gas cleaning as a compliance method. Also, pounds per hour limits can have the effect of restricting facility size. 
In contrast to the SIP development of regulations that are tied to ambient air quality requirements, federal New Source Performance Standards (NSPSs) are based on the use of the best available control technology. Table 2.2 gives the NSPSs promulgated for coal-fired power plants. Note that the NSPSs represent an upper limit on new source emissions, and it is not an acceptable argument for a facility to claim conformance with NSPSs if it does not conform to a SIP. This potential conflict between NSPSs and state regulations could conceivably discourage the development of coal-fired generation capacity in certain areas.

Indeed, certain areas of the country have already effectively banned coal-fired power plants. For example, there is virtually no coal in the eastern and midwestern fields that can meet the $0.5 \%$ sulfur content regulation in Connecticut. Vermont is nearly as restrictive with a $1 \%$ sulfur level limit.

Other states show great variations in the applicable regulations. New York and Pennsylvania both have regions that can use most of the coal now being brought into the area without flue gas desulfurization (FGD), other regions that require only moderate FGD removal efficiencies, and still others that require FGD efficiencies near the current state-of-the-art to ensure compliance.

In many other areas of the country, NSPSs constitute the most stringent regulations applicable to power plants. Variations in sulfur removal requirements then depend primarily on the properties of the available coals.

Table 2.2 Federal New Source Performance Standards for Coal-Fired Power Plants ${ }^{a}$

\begin{tabular}{lc}
\hline Pollutant & $\begin{array}{c}\text { Allowable Emissions } \\
\left(1 \mathrm{~b} / 10^{6} \text { Btu heat input }\right)^{b}\end{array}$ \\
\hline Particulates & 0.1 \\
$\mathrm{SO}_{2}$ & 1.2 \\
$\mathrm{NO}_{\mathbf{x}}{ }^{\mathrm{c}}$ & 0.7 \\
\hline
\end{tabular}

\footnotetext{
${ }^{a}$ Greater than $250 \times 10^{6} \mathrm{Btu} / \mathrm{hr}$ heat input.

b

Maximum 2-hour average.

${ }^{c}$. Expressed as $\mathrm{NO}_{2}$ equivalent.
} 
However, regulations in some of the western states present an unusual pattern. Virtually all of the native coal can meet the NSPSs with little or no sulfur removal, yet stringent state regulations require sulfur removal efficiencies in excess of $80 \%$. In this coal-rich region, more than one-third of the heat input to fossil-fired generators has been derived from oil and gas.

The preceeding discussion indicates the great diversity in regulations faced by the utility industry. The degree of compliance with those regulations is also highly variable at this time. Current particulate limits are within the commercial state-ot-the art for control techniques and compliance is generally being achieved. Ambient $\mathrm{NO}_{2}$ levels are within the regulatory limits in all but a handful of the nation's AQCRs, although the trend seems to be in the direction of more AQCRs approaching or exceeding the standard and this pollutant may receive increased attention in the future. The major problem at this time is $\mathrm{SO}_{2}$ control. In 1975, utilities burned 410 million tons of coal (out of 646 million tons mined) of which 176 million tons (43\%) did not meet sulfur oxides emission regulations. Ninety-three percent of the non-complying coal was burned in the region east of the Mississippi.

Although a sizeable fraction of the nation's coal-fired generating capacity has not as yet achieved compliance with all of the existing standards, additional restrictions are in the planning stages. There has been some discussion as to the development of a short-term $\mathrm{NO}_{2}$ standard, but no definitive timetable has yet been announced. Also in the discussion stage are total sulfur compound, fine particulate, and trace metal standards.

It is possible that the EPA will soon impose much stricter regulations for $\mathrm{NO}_{\mathrm{X}}$ control on stationary sources in general and on utility boilers in particular. This action is being contemplated because of the inability of the automobile industry to meet specitied $\mathrm{NO}_{\mathrm{X}}$ standards without unacceptable fuel economy penalties. Nitrogen oxides emissions of $200 \mathrm{ppm}$ for 1980 and $100 \mathrm{ppm}$ for 1985 are currently being considered by the EPA as research and development goals.

Two other developments of a more general nature are taking place which may have far reaching effects on the utilization and siting of coal-fired power plants. These are the air quality maintenance planning process and the proposed prevention of significant deterioration amendments to the Clean Air Act. 
The air quality maintenance planning process is an extension of the NAAQS/SIP program. The states are now required to extend their SIPs to include the effects of growth and development in areas that could potentially have difficulty in maintaining the NAAQS over a 10-yr planning period. Since the process incorporates concepts of both regional land use planning and traditional technological controls as air pollution abatement mechanisms, this program could conceivably play a significant role in the siting of coalfired plants.

An even more significant impact may result from the proposed amendments to the Clean Air Act that require the prevention of significant deterioration (PSD) of air quality in areas current1y meeting the secondary NAAQSs. Although several versions of the regulations have been proposed, each relles on a classification of various areas according to the pollutant concentration increments to be allowed. Class I designations would be reserved for areas, such as national parks, that are intended to remain pristine. Class II designations would apply to areas where moderate growth. in concentrations could be tolerated as the region grew. Class III designations would be reserved for areas where maximum growth was planned and where the air quality would be allowed to move up to the secondary standards. The states would have the option of determining the classifications.

The potential impact of the PSD regulations on coal-fired power plants is very large. Any moderate-to-large facility can conceivably create pollutant concentration increments in excess of the PSD requirements without even considering the effects of other nearby sources. Thus, these regulations would strongly influence the size and siting of new power plants. A number of studies of the significant deterioration issue have been conducted by a wide variety of organizations. Many of the studies reach opposing conclusions and there are only a few points of common agreement: (1) Class I areas would present a major obstacle to growth due to the surrounding buffer zones which would be required, (2) industry capital costs would increase as a result of PSD regulations, (3) facility size, emission control technology, and siting would be influenced by the regulations, and (4) future growth would be restricted by the elimination of class III areas.

In a eomewhat cimilar. vein, a rccently proposed EPA policy affectIng the location of emissions sources in areas that have not attained the 
NAAQSs could have a significant impact. The areas, called non-attainment areas, may be limited in the amount of emission growth they can tolerate. The policy states that a new source locating in the area or an expansion of an existing source must first of all use the most reasonably available control technology; secondly, in the case of expansions it must be demonstrated that emissions will be reduced elsewhere at the facility to compensate for the increase due to the new additions.

The question of water quality has not received the same degree of attention as air pollution. However, the Environmental Protection Agency has developed effluent limitation guidelines and new source performance standards for wastewater discharges from steam-electric generating plants. These regulations fall into two categories: (1) best practicable control technology currently available (BPCTCA), and (2) best available technology economically achievable (BATEA). These standards must be met by July 1 , 1977 and July 1, 1983 respectively. Other regulations that affect wastewater discharges include receiving water quality standards, pretreatment standards, toxic substance limitations, drinking water standards, and specific state and local standards. 


\section{FUEL OPTIONS}

The achievement of compliance with emissions regulations can be approached in several different ways. In some cases, combustion conditions can be modified such that less of the undesired effluent is produced. Alternatively, flue gas treatment processes may be employed to "clean up" the effluents. Both of these apfroaches are discussed in a later section.

The present topic is the reduction in emissions possible through changes in the fuel fed to the boilers. These changes may be obtained through the use of differenc coals and/or by the processing of coals to eliminate unwanted constituents. Most of the attention in these areas is presently directed at reducing the sulfur content of the coal, inasmuch as compliance with $\mathrm{SO}_{2}$ emission levels by other methods has proven to be both difficult and costly.

\subsection{LOW SULFUR COAL}

Coal inherently low in sulfur is obviously desirable, and indeed there has been a major shift in recent years toward low sulfur coal* use by electric utilities. This unprecedented demand has created uncertainties regarding the future availability and price of this fuel. The uncertainties are particularly difficult to resolve since they involve a number of factors including environmental concerns, constraints on production, and transportation system capabilities and costs.

The transportation situation is important primar1ly because of the geographical distribution of low sulfur coal reserves relative to the major demand centers located in the East and Midwest. Although a small amount of low sulfur coal is found in the East, much of it commands a premium price due to alternate uses in the metallurgical industry. Therefore, the primary source for utility boiler fuel must be the western fields, most of which produce coals which qualify as low sulfur. Not only does this mean that the coal must travel great distances to reach the major customers, but the transportation networks are not as developed in the West, giving less flexibility and competition.

*Coal capable of satisfying the NSPS for $\mathrm{SO}_{2}$ without cleaning or flue gas treatment. 
The western coals also differ physically from those found in the East or Midwest. Unfortunately, most of the differences are of an undesirable nature as far as transportation, storage, and combustion characteristics are concerned. Moisture contents are generally higher, by as much as an order of magnitude in many cases, and the fixed carbon contents are lower. Also, the volatile material component is higher and the ash characteristics differ significantly from eastern coals. An important result of these differences is that the calorific values are lower for western coals and more fuel must be transported, stockpiled, and burned to achieve the eame hcat input realized with coals from other fields.

However, this additional coal may prove difficult to produce. Total coal production is generally expected to reach one billion tons per year by 1985, but current shortages of some mining equipment have raised doubts about the ability of the mining equipment industry to meet the cxpected demand. Presently, explosives, mine roof bolters, loading machines, continuous miners, and walking draglines are all in short supply. The most persistent of these problems will probably be the availability of walking draglines. Projections for 1985 show the supply of these machines still falling slightly short of the demand.

The coal-mining labor force must also be expanded to meet the anticipated production needs. An ample labor supply for strip mining is expected in al1 but the highest demand projections for the post-1980 period. However, serious shortages have been predicted for underground mining in a variety of demand scenarios. These predictions may be overly pessimistic since they do not take into account a number of mitigating factors, including possible increases in labor productivity, new techniques such as 1ong-wall mining, improved continuous mining equipment, new haulage technologies, and the ability of higher wages to induce greater labor force entry. Tn short, the situation is highly uncertain at this time, but a smooth growth path toward the one billion ton level by 1985 may be accomplished with no major labor. shortages.

Nevertheless, the aforementioned difficulties attributable to the lower calorific values of western coal may still impede its use in existing plants. For a generating station presently using midwestern coal transported by unit train, a stockpile sufficient for about 90 days is normally required. 
This supply would have to be increased by about $25 \%$ (in weight) if western coal delivered by train is to be used. Moreover, if the coal is received by barge, a 185-day supply would be needed, at least in the winter season, necessitating a stockpile increase of $150 \%$. These increases imply that coal stockpile land areas, unloading facilities, and coal handling equipment may all have to be expanded to accommodate the larger reserves. Extra precautions to prevent spontaneous combustion will also be required if dried western coal is stockpiled.

For boilers using pulverized coal, the pulverizer capacity would have to be increased by as much as $30 \%$ to handle the larger volume. This would mean the addition of one or two pulverizers for a typical 500 MWe plant. Pulverizer difficulties may alșo be encountered due to the higher moisture content of low sulfur western coals, since balling up of coal during grinding may result.

Higher moisture content and larger quantities of coal may also force boiler modifications in order to achieve efficient operation. For instance, heat lost through the flue gases because of increased moisture may range from two to three percent of the total heat input. Ash characteristics also differ from those of midwestern coals, but no definite conclusions can yet be drawn regarding the slagging and fouling potential of the western coals. Evidence indicates that the severity of the problem depends heavily on the specific coal and boiler characteristics, and may in fact be less in some cases for western coal as. compared to midwestern or eastern varieties.

Syrlnne-fired hoilers have reportedly had problems with incomplete combustion of low sulfur western coal. Excessive carbon carryover has required fine tuning and expensive modifications of burner controls. Derating is sometimes the only answer, with a $22 \%$ loss in capacity reported in one case.

Tests with other boiler types have shown that a derating of up to $35 \%$ may be required for western coal. This was attributed to a combination of factors including lower calorific value, hardness, higher moisture content, and incomplete combustion.

It thus appears that the conversion of existing boilers burning high sulfur midwestern coals to low sulfur western coals is not a simple matter. The operating parameters which are affected by western coal's characteristics 
are summarized below. These factors must be considered prior to a large scale conversion program.

1. Excessive dusting of coal enroute to power plant.

2. Reduced conveyor belt capacity.

3. Decreased pulverizer output (if so equipped).

4. Loss of boiler efficiency.

5. Water-side scale buildup due to decreased slagging.

6. Increased fouling (with high sodium coal).

7. Decreased electrostatic precipitator efficienry heranse of the decrease in sulfur trioxide in the flue gas.

8. Larger dust handling systems.

In addition to these system problems and the possible mining constraints discussed previously, coal cost is another important factor in determining the degree to which low sulfur coal will be utilized. That cost is determined by the interaction of a number of factors. The cost of production naturally plays a key role, but the price received at a given mine is not always directly related to its own production costs. The mining costs which most accurately predict the market price for coal are those of the marginal (highest unit costs) producers in any given region.

Six major low sulfur mining regions have been defined for this study, and production costs for 1985 have been estimated. In the East, the Appalachian Provinces were divided into northern and southern regions to reflect the different coal-type distributions and enable shipping costs to be more accurately determined. The western fields were divided into four parts: (1) the Powder River region of Montana and northern Wynming, (2) the Hanna region of southern Wyoming, (3) the Uinta region of northern Colorado and Utah, and (4) the San Juan region of New Mexico and southern Colorado. This division provides a representative sampling of the quite divergent western coal types, as well as making it possible to define one geographic centroid per region as a shipping point. Production costs for the marginal mine in each region are given in Table 3.1 .

The costs in Table 3.1 are an average for each region and do not reflect any market premiums that might exist for coal low in sulfur. This premium is expected to be no greater than the cost differential between using low sulfur coal directly and using higher sulfur coal with a control technology. Federal Power Commission data on contract prices of coal delivered to 
electric utilities were used to estimate the current price differential between low sulfur coal and coal with an average sulfur content. The calculated 1985 differentials and railhead prices for each region are shown in Table 3.2. Note that the premium is not significant for western coal due

Table 3.1 Coal Production Costs for Marginal Mines in 1985

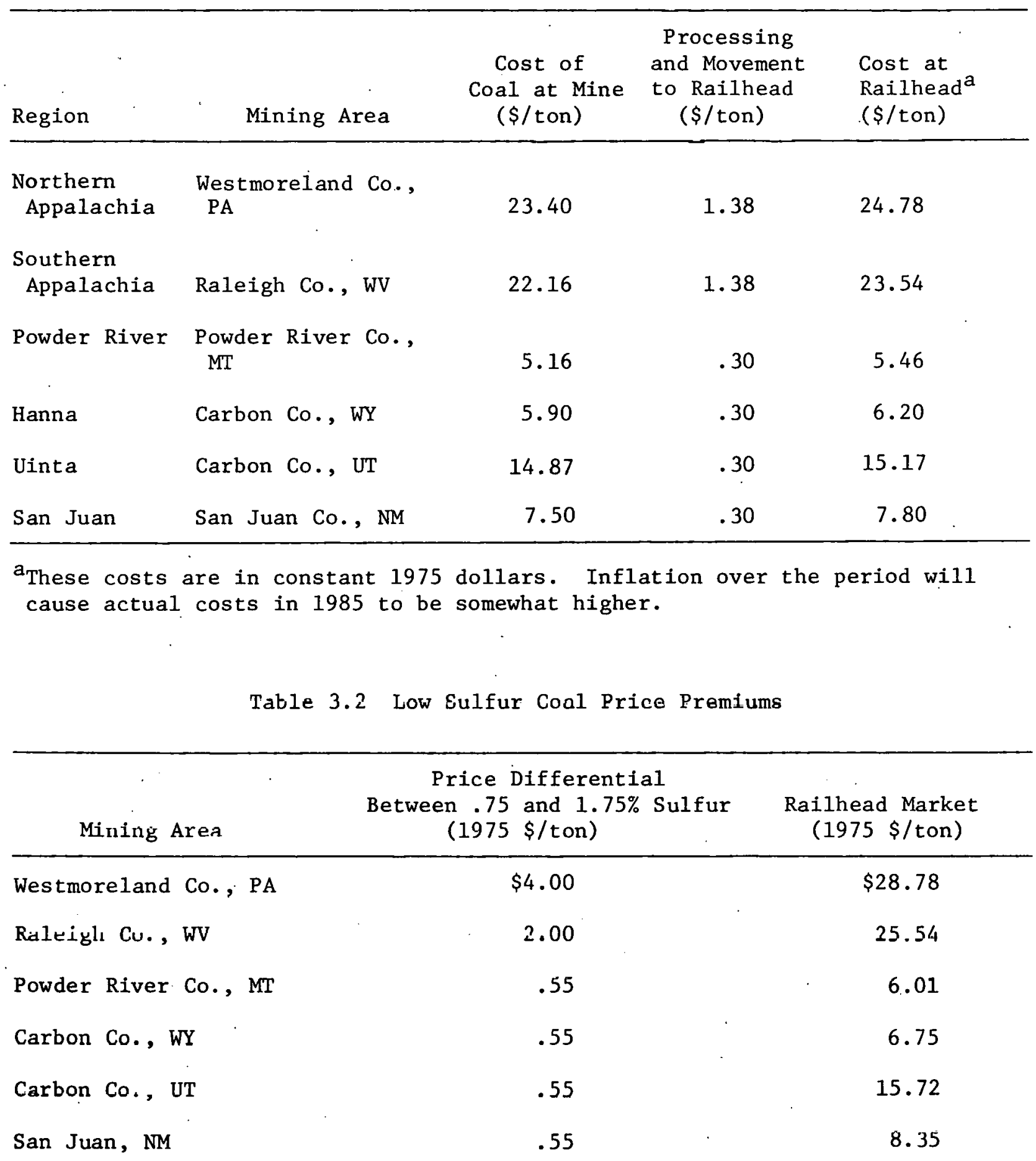


to the high relative abundance of low sulfur coal in those regions. However, the eastern coal values more accurately reflect the correlation with the cost of flue gas desulfurization.

Coal transportation costs have been calculated assuming that rail shipment by unit train will be the primary mode. Average costs of 12, 10, and $8.5 \mathrm{mills}$ per ton mile were assumed for shipments originating in the East, Midwest, and West respectively. Total delivered prices were derived using the previous price estimates in a model that selected the least-cost configurations for coal movements from the six mining regions to 24 demand points. The results are shown in Fig. 3.1 in terms of cents per million Btu at each demand point. The figures indicate that the market boundary between eastern and western low sulfur coal occurs near the Ohio-Indiana horder.

Although none of the specific demand centers considered here can advantageously utilize barge transportation on the Great Lakes, other points may find rail-lake shipments less expensive than an all rail route. Savings can also be significant for utilities which are able to employ the rail-barge mode to ship coal from Appalachia via rivers.

\section{2 COAL PREPARATION}

In addition to low sulfur coal, there is another fuel option available to the ur111ty industry, namely coal preparation. Such processing may be of either a physical or chemical nature (or both), and can upgrade coal quality as well as assist in the control of a number of environmental problems. Chemlcal processing is still in the developmental stage, and is discussed in Chapter 5 of this report. The following discussion deals with the improvetnents in coal characteristics which can be achieved through physical coal cleaning processes in present use.

As an example of the benefits which can be obtained, a recent Bureau of Mines report (RI 8118) states that whereas only $14 \%$ of 455 coals tested could meet the $\mathrm{SO}_{2}$ NSPS directly, $24 \%$ of them met the standard following cleaning at $1.5-i n$. maximum size, and with $90 \%$ Btu recovery. Although this sample is representative of only a small part of the total U.S. coal reserves, the results indicate that significant benefits can be obtained through suitable coal treatment. 


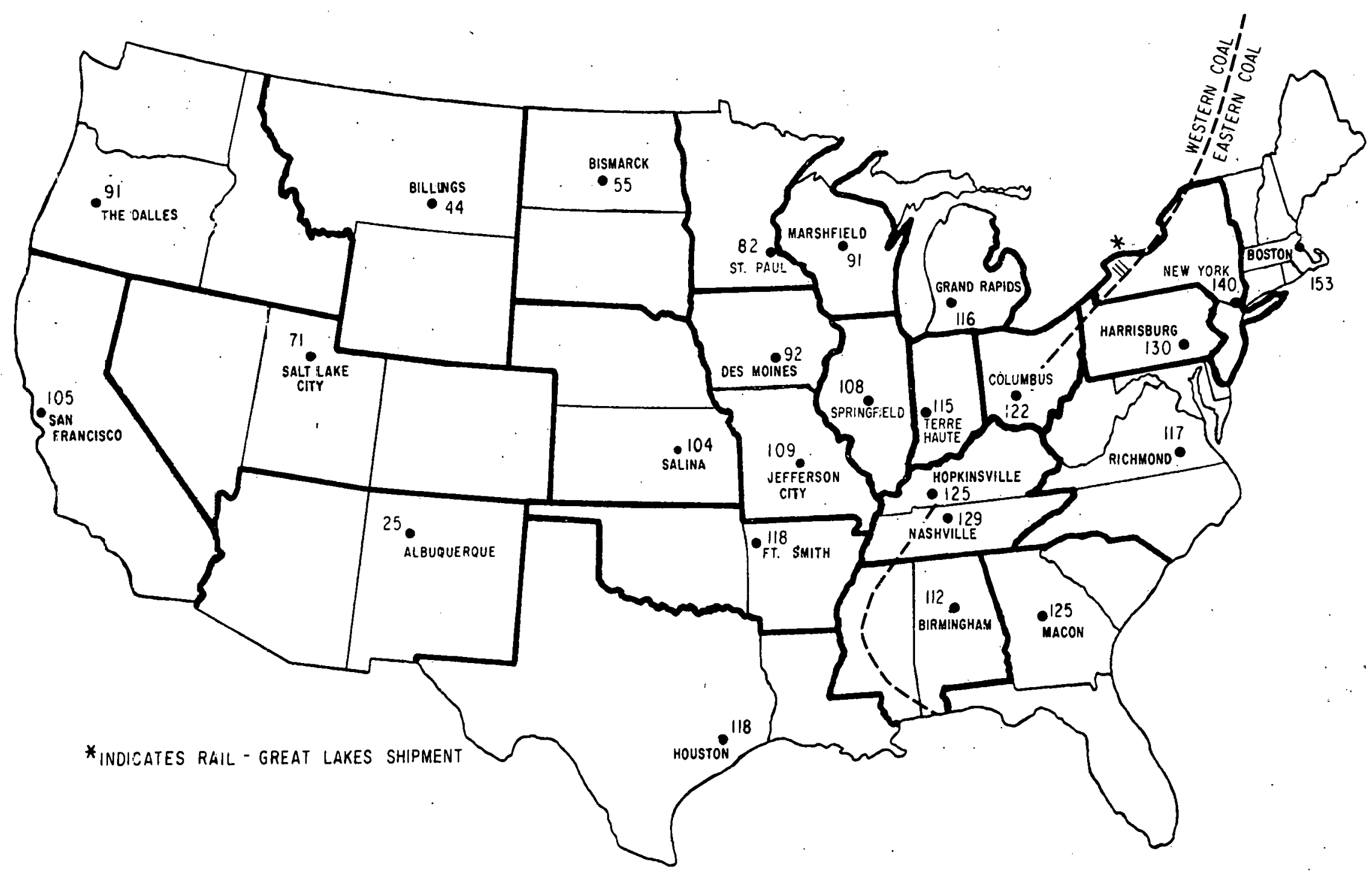

Fig. 3.1 Comparison of 1985 Delivered Prices of Low Sulfur Coal (Cents per Milion Btu) 
There are numerous other advantages of coal preparation in addition to a reduction in sulfur content. These include:

1. Modification of the highly variable raw coal so as to produce a more uniform product with specific properties.

2. Reduction of coal handling and transportation costs.

3. Improvements in combustion reliability and efficiency.

4. Lower costs for pulverization and ash disposal.

Physical coal processing relies upon the liberation of physically compacted components, the separation of the component particles by size and density, and the control of water content in the product coal. Numerous unit operations in many combinations may be employed, and in general the higher the degree of beneficiation required, the more complex and costly will be the preparation operation. Although complete descriptions of the many operations and components are too extensive for inclusion here, several general conclusions can be drawn. These include:

1. Higher quality products result when smaller particle sizes are prepared, since particle homogeneity increases as size decreases.

2. Unit capacities of most coal beneficiation operations decrease with decreasing particle size, thereby increasing both capital and operating costs.

3. Most coals are beneficiated in water media. With decreasing particle size (and increasing surtace area), the process products contain increasing amounts of water that must be removed to approximately $6 \%$ to achieve acceptable handleability and avoid calorific dilution.

Coal preparation processes that are currently practiced or planned on a commerical scale in the United States may be grouped in five levels. Other techniques which are still in the developmental stage are discussed in a later section.

\subsubsection{Level One Processing}

This procedure is designed to remove mine debris and some noncombustible impurities. The unit operations typically include crushing and particle sizing to achieve a uniform saleable product with some improvement in coal heat content, but negligble change in sulfur content. Product yields (material recovery) are generally about $95 \%$ or greater. 


\subsubsection{Level Two Processing}

This procedure represents the minimal processing to create a significant overall quality change. The feed top size is reduced to four to six inches, achieving minimal component liberation. Usually only the plus 3/8-in. or plus 1/4-in. particles and those at a relatively high gravity $\left(>1.5 \mathrm{~g} / \mathrm{cm}^{3}\right)$ are beneficiated. The fine coal is usually neither wetted down nor cleaned. This procedure may result in up to an $80 \%$ or greater yield with moderate ash reduction, but only slight sulfur reduction.

\subsubsection{Level Three Processing}

This level represents many current commercial beneficiation efforts. The coarse particles (>3/8-in. or 1/4-in.) and fine particles (3/8-in. by 28 mesh) are beneficiated in separate circuits while the slimes ( $<28$ mesh) generally are not cleaned. In addition to the liberation achieved by topsize reduction (often to one inch), middling products are sometimes separated and subjected to further liberation and reprocessing. Separations are seldom made at densities less than $1.40 \mathrm{~g} / \mathrm{cm}^{3}$. The processing of fines and slime particles involves complex water quality control circuits, product dewatering, and usually centrifugal as well as thermal drying. Yields are typically about $70-80 \%$ for moderate ash and sulfur rejection.

\subsubsection{Level Four Processing}

This level represents the current "best" or most sophisticated practice generally utilized for the production of metallurgical coals, but it is also finding increasing use for steam-grade coals. It involves both coarse- and fine-coal treatment, as in Level Three, with the addition of froth flotation and other ancillary devices such as vacuum-filters, thermal and centrifugal drying, etc. for treatment of sizes generally below 28 mesh. Product yields are generally about $50-70 \%$ with considerable sulfur and ash reduction.

\subsubsection{Level Five Processing}

This concept, being attempted for the first time in 1976, extends the limits of previous preparation technologies by using selective crushing as well as repeated separations at two or more densities. The final density 
separation will be at as low a level as $1.3 \mathrm{~g} / \mathrm{cm}^{3}$ in a plant circuit achieving maximum liberation, resulting in a practical elimination of the coarse-coal circuit. The process will produce a premium quality clean coal ( $<0.8 \%$ sulfur) with yields of less than $30 \%$, and can only be justified economically if a usable middling product $(2.2 \%$ sulfur $)$ is developed.

Figure 3.2 is a flow diagram of a modern closed-circuit coal preparation plant utilizing Level Four processing. The plants based on this concept typically use heavy media vessels or Baum jigs to treat coarse coal (Level Two). Heavy media cyclones for fine coals may be added to achieve Level Three, and froth flotation for slime recovery is typically used for Level Four. Thermal driers are sometimes added to reduce the water content of products from fine and ultra-fine coal processing circuits, Wastewater is generally treated and recirculated.

Table 3.3 indicates some of the changes in coal quality that can be realized at two cleaning levels as compared to run-of-mine coal. In addition to the reduced sulfur contents, there are dramatic reductions in ash levels. This is the source of the reduced transportation requirements noted previously, and has the additional effect of shifting much of the solid waste disposal burden from the power station to the coal processing plant.

\subsubsection{Preparation Constraints and Costs}

Although coal preparation is a very promising approach for the achievement of environmental standards, there are indeed certain constraints on its use. These can be generally grouped into technical, environmental control, and economic categories.

In the technical area, there are several coal characteristics that can limit the effectiveness of coal cleaning operations. These include the coal component particle sizes, the difficulty of component liberation, and the relative amounts of near-gravity material. Furthermore, sulfur occurs in both organically-bound and pyrite forms, with the organic sulfur generally considered to be inaccessible to mechanical cleaning methods. The organic sulfur thus constitutes a lower limit for sulfur removal by physical preparation. This limit is quite variable, since the ratio of organic to pyritic sulfur can vary greatly from seam to seam, as well as within a single seam. The actual removal achieved also depends on the pyritic sulfur reduction 


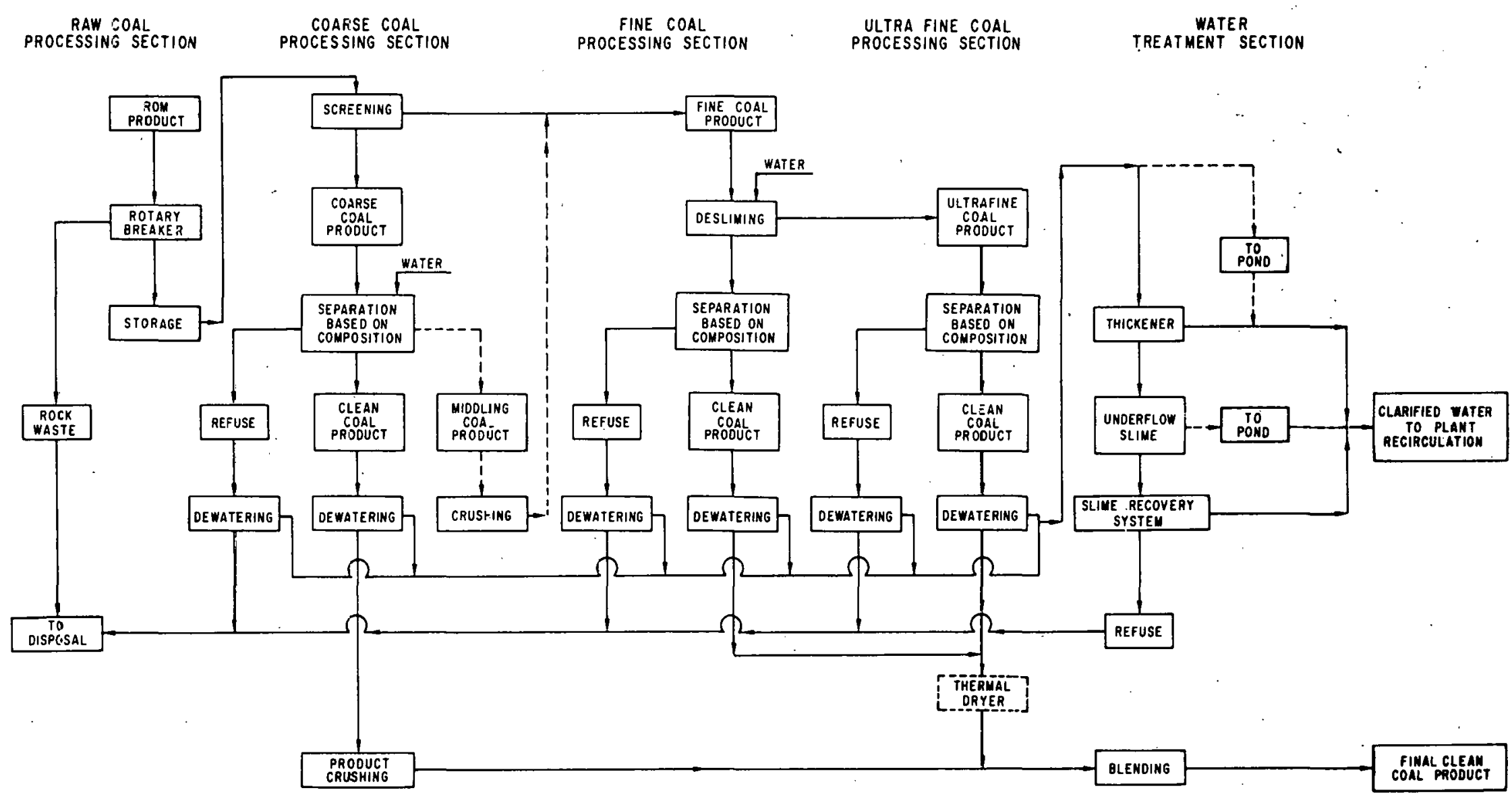

- - - alterate RoUt:

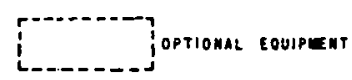

Fig. 3.2 Schematic Flow Diagram of Closed Circuit Coal Preparation Plant 
Table 3.3 Enhancement of Coal Quality by Beneficiation ${ }^{\text {a }}$

\begin{tabular}{|c|c|c|c|c|}
\hline \multirow[b]{2}{*}{$\begin{array}{c}\text { Coal. Source } \\
\text { Region }\end{array}$} & \multicolumn{4}{|c|}{ Coal Characteristics ${ }^{b}$} \\
\hline & $\begin{array}{l}\text { Coal Seam } \\
\text { Analysis }\end{array}$ & $\begin{array}{l}\text { As } \\
\text { Mined }\end{array}$ & $\begin{array}{l}\text { Level } 3^{\mathrm{d}} \\
\text { Bene- } \\
\text { ficiation }\end{array}$ & $\begin{array}{l}\text { Leve1 } 4 \\
\text { Bene- } \\
\text { ficiation }\end{array}$ \\
\hline \multicolumn{5}{|l|}{ Northern Appalachian } \\
\hline Ash $(\%)$ & 14.7 & 17.7 & 7.4 & 5.8 \\
\hline Sulfur (\%) & 3.07 & 2.98 & 1.96 & 1.62 \\
\hline$B t u / \perp b$ & 11,475 & 11,120 & 12,821 & 13,233 \\
\hline Ibs $\mathrm{SO}_{2} / 10^{6} \mathrm{Btu}$ & 5.08 & 5.08 & 2.90 & 2.32 \\
\hline \multicolumn{5}{|l|}{ Southern Applachian } \\
\hline Ash $(\%)$ & 11.2 & 14.2 & 4.3 & 3.9 \\
\hline Sulfur $(\%)$ & 0.93 & 0.90 & 0.81 & 0.81 \\
\hline Btu/Ib & 12,720 & 12,330 & 14,030 & 14,261 \\
\hline Ibs $\mathrm{SO}_{2} / 10^{6} \mathrm{Btu}$ & 1.61 & 1.61 & 1.10 & 1.08 \\
\hline \multicolumn{5}{|c|}{ Mid-Western (Eastern Block) } \\
\hline Ash (\%) & 14.1 & 17.1 & 7.0 & 5.3 \\
\hline Sulfur (\%) & 3.92 & 3.80 & 2.72 & 2.47 \\
\hline Btu/1b & 11,412 & 11,070 & 12,714 & 13,134 \\
\hline lbs $\mathrm{SO}_{2} / 10^{6} \mathrm{Btu}$ & 6.52 & 6.52 & 4.06 & 3.57 \\
\hline \multicolumn{5}{|c|}{ Mid-Western (Western Block) } \\
\hline Asli $(\%)$ & 14.5 & 17.5 & 6.5 & 5.8 \\
\hline Sulfur (\%) & 3.72 & 3.61 & 2.15 & 2.06 \\
\hline Btu/1b & 11,018 & 10,680 & 12,425 & 12,674 \\
\hline Ibs $\mathrm{SO}_{2} / 10^{6} \mathrm{Btu}$ & 6.41 & 6.41 & 3.29 & 3.00 \\
\hline
\end{tabular}

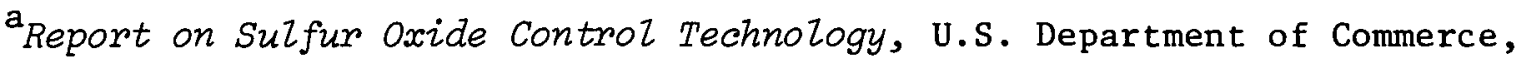
Commerce Technical Advisory Board (Sept 1975).

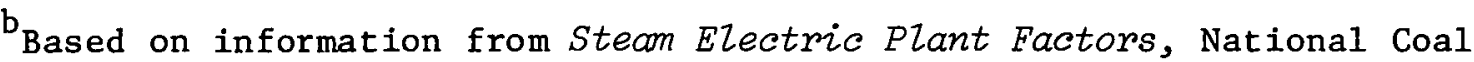
Association, Washington, D.C. (1974), and A. W. Deurbrouch, Sulfur Reduction Potential of the Coals of the United States, Report of Investigation 7633, U.S. Bureau of Mines (1972).

${ }^{c}$ Run-of-Mine (ROM) coal. Assumes the ash content is increased by $3 \%$ due to inert material added by the mining operation.

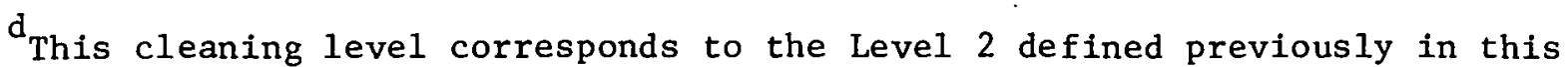
report. 
potential of the coal, and this can vary from less than 10 to more than $90 \%$, depending on the characteristics listed above.

From an equipment point of view, the major constraints are in the area of processing the very fine particles which are required for maximum component liberation and product recovery. The use of operations requiring ultrafine particles generally results in lower unit capacities, reduced separation efficiencies and yields, greater costs, greater difficulty in complying with environmental regulations, and more extensive dewatering systems.

The most significant environmental control problems associated with present coal preparation facilities are: (1) closing of the plant water circuit for zero process water discharge to the environment, (2) disposal of sludge from the wastewater treatment systems, (3) prevention of drainage and runoff from coal storage and refuse, and (4) noise control for crushing and grinding operations.

The costs of dealing with all of the above factors contribute to the ultimate cost of cleaned coal, and that cost is a primary factor in determining the extent to which such fuel will be used by the utility industry: In particular, the use of beneficiated coal must compare favorably with other options available to meet pollutant emissions standards. In that context, a recent U.S. Department of Commerce study concluded that coal cleaning would produce an incremental increase in generating costs of from 0.5 to 2 mills per $\mathrm{kWh}$. On the other hand, the incremental cost for 1ime/1imestone flue gas desulfurization was 4 to 6 mills per $\mathrm{kWh}$.

In those sltuations where acceptable low sultur coals are not available or coals cannot be totally cleaned to meet existing sulfur emission regulations, combinations of coal preparation and flue gas desulfurization appear promising. The removal of sulfur and mineral matter refuse by washing reduces the amount of $\mathrm{SO}_{2}$ to be removed by flue gas processing, lowers the amount of lime/limestone required, with a consequent reduction in sludge and ash, and gives an overall cost advantage in many instances. Specific site, market, and lead-time constraints w111 determine the most economical and practical control technology. mix for a given plant. 


\section{CONVENTIONAL COMBUSTION}

The existing coal-fired generating capacity in the United States represents a tremendous investment on the part of the utility industry. Approximately 200,000 MWe, or $40 \%$ of the total capacity, is now fueled with coal. The magnitude of that commitment, the tendency for long-term coal contracts which inhibit rapid changes in fuel type, and the uncertainties in the costs or feasibilities of other types of plants have placed a heavy emphasis on devising "clean up" techniques for conventional boiler effluents.

As discussed in the preceding sections, the major atmospheric pollutants, $\mathrm{SO}_{2}, \mathrm{NO}_{\mathrm{X}}$, and particulates, have received the greatest attention because each has been implicated as a cause of respiratory problems. To place the "clean up" task in perspective, note that the average utility coal in 1973 had $2.32 \% \mathrm{~S}, 13.29 \% \mathrm{ash}$, and a heat content of $11,090 \mathrm{Btu} / 1 \mathrm{~b} . *$ If such a coal were burned in a plant subject to NSPSs, removal of $72 \%$ of the $\mathrm{SO}_{2}$ from the flue gas would be required. If the $f l y$ ash were $80 \%$ of the total ash, as is typical in modern pulverized coal furnaces, a particulate collection efficiency of 99\% would be required. If $\mathrm{NO}_{\mathrm{X}}$ emissions corresponded to the 1972 level from coal-fired boilers of about $740 \mathrm{ppm}$, a $30 \%$ reduction would be required.

The more conservative projections of electrical demand indicate that coal-fired generating capacity in 1985 will be somewhat more than 300,000 MWe and that coal consumption by the utilities will be about 700 million tons per year. Thus, during the next ten years more than 100,000 MWe of coal-fired plants incorporating environmental controls to meet NSPSs will have to be installed. The selection of the control technologies and the selection of coal supply for the plants are highly interdependent and must be made at an early stage in the planning process because of the long lead times for new coal mines. The selections are also essentially irrevocable because the development of a new mine is rarely undertaken without a long-term contract in hand. Since costs for the pollution controls are substantial (up to $15 \%$ of total cost), it is important that the decisions made by the ulililies reflect the latest information on performance, costs, and anticipated developments.

\footnotetext{
* Source: Steam-Electric Plant Air and Water Quality Control Data, Federal Power Commission, Washington (Jan. 1976).
} 


\subsection{FLUE GAS DESULFURIZATION (FGD)}

The control of sulfur oxides in the power plant emissions has been the major subject of discussion and developmental effort. The earlier controversy between the EPA and utilities over the acceptability of tall stacks and intermittent control as a means of limiting $\mathrm{SO}_{2}$ emissions has now been stilled by actions of the U.S. Supreme Court indicating that control must be achieved by continuous limitation of emissions. The utilities must therefore either burn a clean fuel or remove $\mathrm{SO}_{2}$ after formation. The currently available precombustion options, use of low sulfur coal and of coal cleaning, were discussed previously. The currently available postcombustion option, FGD, will be discussed at this point, and the developing technology of fluidizedbed combustion will be considered later.

FGD is the generic name used to denote processes for the chemical and physical removal of $\mathrm{SO}_{2}$ from flue gas, usually by means of a gas scrubbing operation. The feasibility of achieving efficient $\mathrm{SO}_{2}$ removal from both high and low sulfur coals by FGD has been demonstrated at commercial ( $>100 \mathrm{MWe}$ ) scale, but concerns still exist regarding the reliability, costs, and waste disposal problems of FGD systems. Nonetheless, FGD is the only available option that will allow a utility to burn high sulfur coal and still meet the NSPS. It is also the only option available for compliance with more strict state/local regulations that require reduction of $\mathrm{SO}_{2}$ emissions even when burning low sulfur coal. It is noteworthy that FGD systems planned by the utilities are divided about equally between the two types of application.

FGD systems can be of various types. They are termed wet processes if the $\mathrm{SO}_{2}$ is absorbed in a scrubbing operation and dry if the $\mathrm{SO}_{2}$ is adsorbed on or reacts with a solid. They are termed throwaway if the sulfur product is worthless, and regenerable if the product is marketable (e.g., sulfur or sulfuric acid). Effort in the U.S. has been concentrated on wet, throwaway processes, especially on those involving use of lime or limestone (L/LS). Processes based on L/LS are used in more than $80 \%$ of installed FGD systems and have been selected for more than $90 \%$ of those planned. The use of L/LS slurries in wet scrubbers has been demonstrated to provide $\mathrm{SO}_{2}$ removal efficiencies of $80-90 \%$, but the development of systems that operate reliably has been hampered by numerous problems. The major problem has been the deposition of solids, resulting in plugging of the scrubbers, the reheater, 
and particularly the mist eliminator. The problem is made more severe by the limited amount of fresh wash water that can be used in closed loop operation. Additional operating problems have been caused by corrosion and by erosion of pumps and protective linings. Improvements in process control and construction materials are resulting in improved performance of FGD systems, but the number of systems operating is still too few to permit a valid judgment of FGD reliability in general.

The problems encountered with direct use of L/LS slurries have led to increasing interest in the double alkali process, in which a solution of alkali serves as the primary sorbent and is regenerated in a separate vessel by treatment with L/LS slurry. The use of an alkali sorbent permits higher removal efficiencies (up to 95\%) and reduces scaling problems in the scrubber, but the regeneration step produces the same undesirable sludges of calcium sulfite and sulfate as direct L/LS scrubbing. The strong tendency of the calcium sulfite crystals to occlude moisture makes it impossible to mechanically dewater the sludges to the extent necessary for use as landfill.

The problems with throwaway systems have led to the commercial development of a number of regenerable FGD processes, both wet and dry. Several are operating in Japan, but to date no process producing sulfur or sulfuric acid has been satisfactorily demonstrated in the U.S. An EPA-funded demonstration of the magnesium oxide scrubbing process, in which spent sorbent is regenerated by calcination at an off-sice sulfuric ac1d plant, was operated on an oil-fired boiler by Boston Edison, but the program was terminated before loss of $\mathrm{MgO}$ from the system was brought to an acceptably low level. (An installation on a coal-fired boiler now classified as operational has actually been used only for particulate removal.) A demonstration of the Cat-Ox system, which yields a lower grade (80\%) sulfuric acid, was initiated in 1972, but has been indefinitely postponed. The Foster Wheeler-Bergbau forschung process, in which sulfur is produced via adsorption on activated carbon, operated briefly in 1976 on a 23-MWe slipstream, but further demonstration of this process has also been indefinitely postponed.

Still pending is a 115-MWe demonstration of the Wellman-Lord process initially scheduled to start in mid-1974. 'In this process $\mathrm{SO}_{2}$ is absorbed in a solution of $\mathrm{Na}_{2} \mathrm{SO}_{3}$, re-evolved thermally, and reduced to sulfur with natural gas. Demonstration programs have been announced for a Citrate 
process developed by the Bureau of Mines and for the proprietary Aqueous Carbonate process; both are wet processes with a sulfur product. Even if these demonstrations are successful however, it is unlikely that any regenerable process will be extensively deployed before 1985 .

The current status of FGD systems in the U.S. is detailed in bimonthly reports prepared by PEDCo under an EPA contract. The summary from the JulyAugust 1976 report, reproduced here as Table 4.1, classifies 30 FGD systems installed on 6396 MWe as operational and indicates that installation of a total of 116 systems on 43,580 MWe is planned. The number of operating systems appears to belie the earlier comment on the paucity of examples for judging the reliability of scrubbers, but fully two-thirds of the units provide no meaningful information about the operation of a L/LS scrubber on the large base-load power plants that utilities are planning. The 30 systems classified as operational include:

1. Four obsolete systems slated for replacement,

2. Two systems operated only for particulate removal,

3. Two small (10 MWe) testing units at TVA,

4. Five small (>40 MWe) demos for less-developed processes,

5. Three systems of limited applicability (soluble throwaway),

6. Four systems on older plants not regularly used, and

7. One system to be shut down after brief testing.

The remaining nine systems all use L/LS scrubbing; five are installed on western plants burning low sulfur coal and four are installed on plants

Table 4.1. Number and Total MWe of FGD Systems

\begin{tabular}{lrr} 
Status & MWe \\
\hline Operational & 30 & 6,396 \\
Under Const ruction & 21 & 8,244 \\
Planning & 19 & 9,695 \\
$\quad$ Contract awarded & 6 & 1,442 \\
Letter of intent & 8 & 3,727 \\
Requesting/evaluating bids & 32 & $1.4,076$ \\
Considering only FGD systems & 116 & 43,580 \\
\hline
\end{tabular}


burning high sulfur $(>2 \%)$ coals. The distinction is made because it is easier to achieve reliable FGD with low inlet concentrations of $\mathrm{SO}_{2}$, particularly in an arid climate where evaporation from waste disposal ponds allows greater quantities of fresh water to be added to the system for washing. Seven of the nine systems started operation within the past year and information on their performance is very limited. In only two cases therefore, at the Cholla Station of Arizona Public Service and at the La Cygne Station of Kansas City Power and Light, has reliability of greater than $80 \%$ on a major ( $>100 \mathrm{MWe}$ ) installation been demonstrated for a year or more. At the La Cygne Station, which uses a high sulfur $(5.4 \% \mathrm{~S})$ coal, reliable operation has been achieved only with an intensive maintenance program that has involved taking one of the seven FGD trains out of service each night for cleaning and has required the services of more than 50 people, one-fourth of the plant personnel. Some of the newer systems, including two on plants using high sulfur coal, have been reported to be operating with high reliability however, and their continued success conceivably could have an accelerating effect on deployment of FGD in the early 1980s.

Uncertainties regarding costs of FGD systems present an additional obstacle to their acceptance by the utilities. At the panel disrussinn nf a recent symposium, for example, the experts' estimates of the capital costs for FGD systems ranged from $\$ 55-145 / \mathrm{kW}$. It should be recognized however, that the costs of FGD systems are influenced by a large number of factors, and that discrepancies in estimates are not nearly so large when care is taken to specify all the factors and make comparisons on a reasonably common basis. Among the more important factors are the size of the system, the sulfur content of the fuel, the degree of redundancy selected, the equipment requirements and energy penalties of the FGD process, and the type of installation (new or retrofit). Unit costs of FGD systems decrease with increasing plant s1ze, even though gas trains are modularized to handle about 150 MWe of flue gas, because of economies of scale in the costs of solids handling equipment and general construction, and because redundancy costs are less. The costs increase with increasing sulfur content in the fuel because the requirements for solids handling equipment and for waste disposal are greater. Capital costs of regenerable systems are appreciably higher because energy penalties in some of the processes range up to $10 \%$ as compared to $4 \%$ in L/LS scrubbing. 
Recent cost studies by TVA and PEDCo have made substantial progress toward quantifying these factors and providing a methodology for estimating costs. Estimates for L/LS scrubbing are the most meaningful because of the greater amount of information available, but substantial uncertainties are introduced by variations in site-specific factors such as those related to waste disposal. Projected capital costs for a LS scrubbing system installed on a new 500-MWe power plant burning $3.5 \% \mathrm{~s}$ coal might range from $\$ 70-100 / \mathrm{kW}$. Annualized costs based on a load factor of 0.80 might range from 4-6 mills/ $\mathrm{kWh}$, about $20 \%$ of busbar costs. The costs of regenerable FGD are subject to even greater uncertainties since data on operating systems are not available, but estimated costs (including by-product credits) have ranged from $25 \%$ less to $25 \%$ more than those for L/LS, depending on the energy requirements of the processes.

Where the FGD system must be retrofitted costs can be much higher. For instance, the annualized costs in a model study by PEDCo for a FGD system installed on a plant with a remaining life of 15 years were twice those for installation on a plant with a 30-year 1ife. In a TVA study (Bucy, 1976) on economics of sulfur abatement, it is noted that $83 \%$ of the coal and oil-fired boilers in the East were 11-15 years old in 1972. If plans were initiated now to install FGD on these plants, the boilers would be $20-25$ years old by the time the FGD was operable. For such units, it appears advantageous to shift the economic burden to operating costs and use either low sulfur coal, washed coal, or a solvent-refined coal (SRC) to achieve compliance with emission regulations.

The comparative costs of FGD and other options for control of $\mathrm{SO}_{2}$ vary with the location of the power plant as well as its age. In the East, a limited number of coals, chiefly those in southern Appalachia, can meet the NSPS directly or can be physically cleaned to that level without great difficulty. Such coals will command some price premium, but should still be the lowest cost option for power plants located within a few hundred miles. There is a substantially larger number of eastern coals that have sulfur contents, before or after cleaning, such that the NSPS can be met by removing $60 \%$ or less of the $\mathrm{SO}_{2}$ from the stack gases. For power plants with such coal supplies $\left(<1.51 \mathrm{~b} \mathrm{~S} / 10^{6} \mathrm{Btu}\right)$, the NSPS could be met at lowest cost by applying FGD to only a fraction of the flue gas. If, for example, a coal initially 
containing $3 \% \mathrm{~S}$ can be upgraded by physical cleaning to $1 \mathrm{lb} \mathrm{s} / 10^{6}$ Btu (e.g., $1.4 \% \mathrm{~S}$ at $14,000 \mathrm{Btu} / \mathrm{lb}$ ) then $\mathrm{FGD}$, at $85 \%$ efficiency, is required for only one-half of the stack gas. In this case fixed costs for a FGD system on a 1000-MWe plant would be reduced by $1.5 \mathrm{mills} / \mathrm{kWh}$, and costs for operation and waste disposal would be about $2 \mathrm{mills} / \mathrm{kWh}$ lower. Overall savings could be more than $1 \mathrm{mill} / \mathrm{kWh}$ even if the coal beneficiation involved elaborate cleaning at $\$ 5-8 /$ ton.

The comparative costs of using FGD versus low sulfur western coal to meet the NSPS are more difficult to define since they are so sensitive to the location of the power plant. The cost of a plant deslgned for operation on low sulfur western coal might be expected to be about $\$ 15-25 / \mathrm{kWe}$ higher than a corresponding plant designed for a midwestern coal, but about $\$ 55-75 / \mathrm{kWe}$ less than a FGD-equipped plant. The decrease in fixed costs afforded by use of western coal, together with the decrease in waste disposal costs, could result in a savings of $3-4 \mathrm{mills} / \mathrm{kWh}$, approximately $30-40 \mathrm{c} / 10^{6} \mathrm{Btu}$. Western coal is therefore economically competitive with FGD at plants where the delivered price does not exceed that of local coal by more than this amount. Recent price information indicates western coal transported by rail is competitive with local coal at non-minemouth power plants in most states bordering the Mississippi; via rail-barge transport on the Great Lakes it can be competitive as far east as ohio.

In view of the many uncertainties, projections of FGD deployment are pointless at this time. The EPA has estimated that scrubbers for 90,000 MWe will be needed to meet 1980 sulfur oxide standards. In its transition papers to the Carter Administration the agency noted that planned installation of 116 FGD systems on 43,580 MWe of generating capacity (cf. Table 4.1) represent about $50 \%$ of the amount needed by 1980 , but it provided no breakdown on the locations or startup dates of the installations. The need for FGD is clearly on power plants in states east of the Mississippi, where 93\% of the 176 million tons of non-complying utility coal was burned in 1975. This tonnage corresponds, at the average load factor of 0.5 , to a non-complying capacity in the East of about 80,000 MWe. Analysis of the data on which Table 4.1 is based reveals that plans call for installation of FGD systems through 1980 on only 17,358 MWe of eastern and midwestern power plants that burn high sulfur $(>1 \% \mathrm{~S})$ coal. As shown in Figure 4.1 , this is less than one-fifth of the needed amount. Installation of FGD systems on an additional 3050 MWe of 


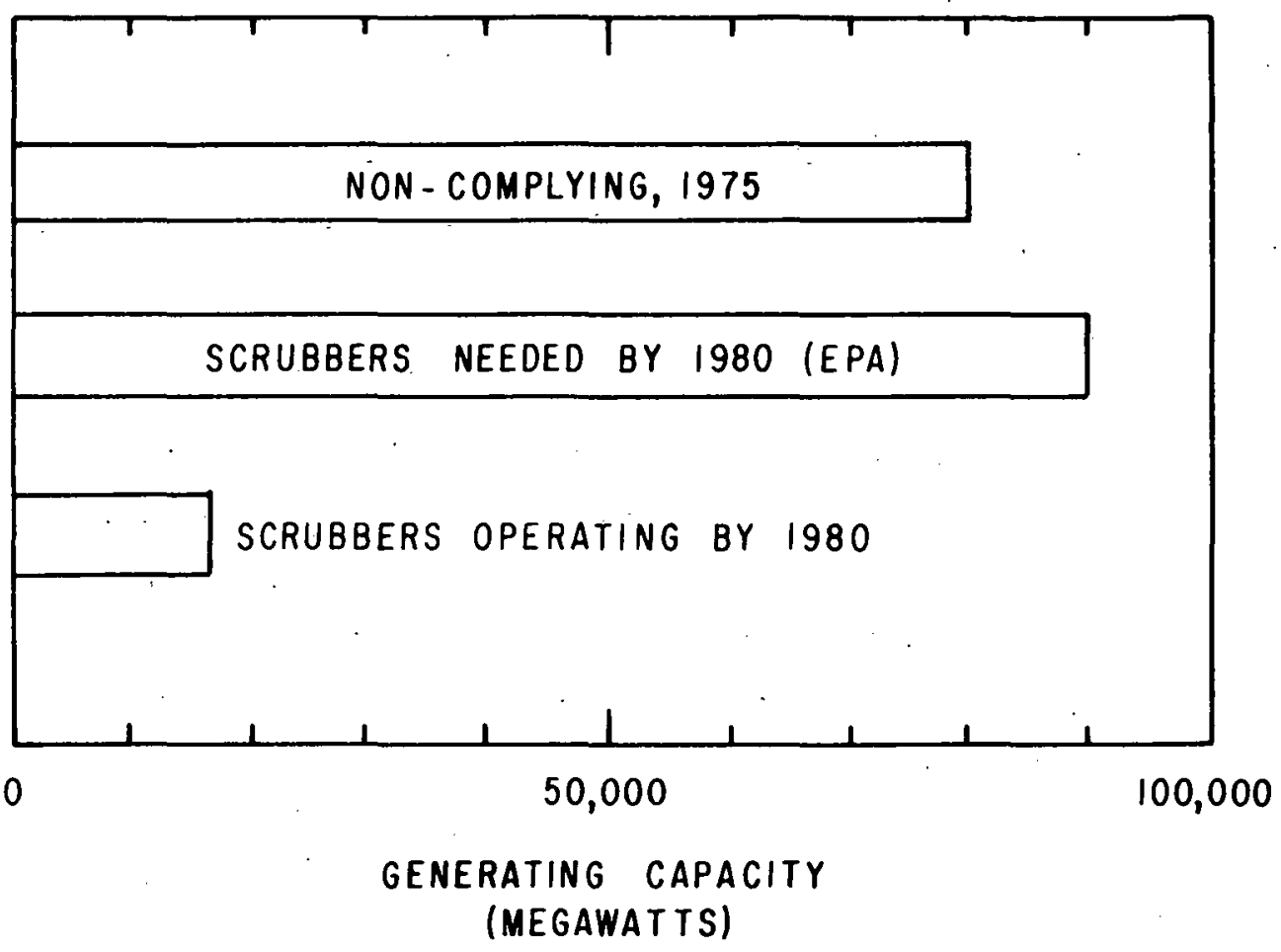

Fig. 4.1 Sulfur Oxides Emissions Control for Coa1-Fired Power Plants in Eastern U.S.

eastern plants is planned for after 1980; the remaining systems will be installed on western power plants that burn low sulfur coal.

Plans for further deployment of FGD can be markedly affected by pending legislation on Clean Air Act amendments (S.253, 95th Congress). Provisions calling for use of the best available control technology (BACT) would preclude use of low sulfur coal without other control technology and require use of FGD on all new coal-fired power plants. If FGD deployment is accelerated, a number of problems can be anticipated. A major one is that of waste disposal. At the present time, when no regenerable process has been demonstrated, selection of an FGD system is effectively restricted to throwaway processes using L/LS. A new 1000-MWe plant equipped with a limestone scrubber and burning coal with. $3 \% \mathrm{~S}$ and $12 \%$ ash will produce in the first ten years of operation a quantity of waste that covers I sq mile to a depth of $12 \mathrm{ft}$. Use of such systems on the more than 100,000 MWe of coal-fired plants to be constructed in the next ten years, and on some existing ones, could create a massive waste disposal problem. 


\subsection{PARTICULATE CONTROL}

Whatever sulfur oxide control method is selected, the process must be evaluated in light of existing or planned flue gas particulate control techniques, inasmuch as their control and waste disposal problems are highly intertwined. Fortunately, the achievement of adequate particulate control has proven to be relatively straightforward, and several techniques are commercially available.

Electric utilities have been removing particulates for many years by mechanical means (cyclones) or by electrostatic precipitation (ESH). About three-fourths of all power plants, and an even larger fraction of the newer large plants, are already equipped with ESP. More than $90 \%$ of the fly ash produced is being collected at the present time. Particulate control, in fact, has been considered to pose no particular problems. Two recent developments, however, have drastically altered the situation: these are (1) the increasing use of low sulfur coal to meet $\mathrm{SO}_{2}$ emission standards, and (2) the spectre that regulations may be imposed on the emission of fine particulates $(<1 \mu \mathrm{m}$ in diameter).

The problems arise from inherent features of particulate collection by ESP. In an electrostatic precipitator, the particles become charged by negative ions generated in an electrical corona produced by application of a high DC voltage to a small wire. Under the influence of the electrical field, the charged particles migrate to a positive plate where they are deposited and, by physical means, subsequently collected. Two parameters have especially important effects on the efficiency of collection--the resistivity and the size of the particles. As the resistivity of the particles increases, the electrical current that can be maintained in the precipitator without excessive electrical breakdown (sparking) in the dust collected on the plate decreases and, hence, the rate of charging of the particles decreases. Thus, a greater plate area, with a correspondingly greater size and capital cost for the precipitator, is required to achieve an equivalent amount of particle charging. Since the resistivity of fly ash increases as the sulfur content of the coal decreases (largely because less $\mathrm{SO}_{3}$ is formed and adsorbed on the particles), a change to the use of low sulfur coal will generally require an increase in size and cost for ESP. For a collection efficiency of 99.5\% (as might be required to meet the NSPS), ESP costs for high resistivity 
fly ash might be nearly double those for fly ash of moderate or low resistivity. The effects of a high resistivity can be ameliorated to some extent by the deliberate injection into the flue gas of $\mathrm{SO}_{3}$ or other substances which can promote electrical charging. They can also be reduced by injection of substances which promote the agglomeration, and hence the collection, of small particles. The use of such conditioning agents is increasing markedly, and it would appear important to determine whether or not these practices result in any adverse secondary emissions.

Particle size is important in ESP because particles are charged by two different mechanisms. Charging of particles greater than $1 \mu \mathrm{m}$ in diameter occurs by field charging (intercepetion of the electrical field lines along which the ions trave1), whereas charging of those less than $0.2 \mu \mathrm{m}$ in diameter occurs by diffusion charging (random thermal collisions with ions). Particles in the intermediate size range, between 0.2 and $1 \mathrm{\mu m}$ in diameter, are charged by both mechanisms, but less effectively. Thus, collection efficiency reaches a minimum in this range such that the mass of such particles which escape collection is 50-100 times as great at that for larger or smaller sizes. Particles in this size range are respirable and able to enter the lower respiratory areas where they become lodged. The surrounding tissue can then be subjected to the effects of substances adsorbed on the surface of the particles, such as trace metals or carcinogenic compounds, for extended periods (see Chapter 2). The health hazards associated with fine particulates provide a possible motivation for the promulgation of emissions regulations tied to particle sizes. Such regulations could present serious problems for power plant operators, inasmuch as increases in the efficiency of ESP become progressively more difficult and costly to attain as an ever increasing fraction of the residual particles are of the size most difficult to collect.

Other factors influencing precipitator performance include reentrainment of collected dust and bypassing of dust-laden gases around the electrified regions. Recent studies indicate that $25-40 \%$ of the total emission from a precipitator is reentrained dust. This effect can be considerably reduced by proper baffling and design of dust removal devices. Flue gas conditioning agents that promote agglomeration, such as ammonia, have also proven useful in this regard. 
Gas flow uniformity also influences collection efficiency. The flow is in turn determined by the duct sizes and configurations, which may be constrained by the available installation space. It is recomended that $85 \%$ of the local gas velocities should be within $25 \%$ of the mean, and that no local velocity deviate more than $40 \%$.

Generally satisfactory performance has been obtalned with precipitators now in operation. However, several problems have been encountered. These include corona electrode failure, overloading or malfunction of the ash removal system, ash buildup in flues and ducts, and insulator breakdowns.

One of the advantages of electrostatic prccipitatore over other particulate control methods is the relatively low energy consumption involved. For a precipitator instalied on a 500 iwe plant pruduclng $1.75 \times 10^{\mathrm{h}}$ ac $\mathrm{fm}$ of flue gas, the total power required to achieve $99 \%$ collection efficiency wuuld be $1488 \mathrm{~kW}$, or about $0.3 \%$ of the plant capacity.

Capital and operating costs for precipitators have been estimated from 1969 Industrial Gas Cleaning Institute data. Installed capital costs for a precipitator with a specific collection area of $400 \mathrm{ft}^{2} / 1000$ acfm are $\$ 23 / \mathrm{kW}$ in 1976 dollars (assuming $3500 \mathrm{acfm} / \mathrm{MW}$ ). Total costs, based on 6000 hours per year of operation, are about $1 \mathrm{mill} / \mathrm{kWh}$.

A second technique for particulate removal that has been receiving increased attention is the use of fabric filters. They can function effectively with particle sizes and electrical properties that are difficult to handle with ESP, making them potentially attractive for plants burning low sulfur coal.

In the filtration of stack gases, the fabric is usually formed into a vertically hung tube or sleeve closed at the top. The gases are drawn through the bag with dust forming a loosely deposited cake on the inside. Periodically, the flue gas flow is turned off and the dust is removed from the fabric by agitation or air backflow and deposited in a disposal hopper.

The type of fabric that has given the best service on power boilers is woven glass fiber coated with graphite and fluorocarbon polymers. However, polyester, cotton, and wool fabrics have also been used. 
Filters have a general disadvantage of high maintenance costs as compared to ESP. Also, the operating energy requirements are higher since a pressure drop of 3-4 inches (water gauge) must be maintained across the filter in a baghouse. By comparison, the pressure drop across in ESP unit is only about 0.5-1 inch. The use of filters is thus considered primarily for installations burning low sulfur coal and producing high-resistivity fly ash that is difficult and expensive to collect with ESP.

Actual performance data is somewhat limited at this time and restricted to relatively small units. The Sunbury Station in Pennsylvania has operated since 1973 and demonstrated an overall mass collection efficiency of $99.2 \%$ for baghouses serving 175 of its 402 MWe. At the Nucla Station in Colorado ( 39 MWe), a mean mass collection efficiency of $99.84 \%$ was measured.

Another technique for fly ash removal is the wet scrubber. This may be used for particulates alone or, more commonly, for both fly ash and sulfur dioxide. Scrubbers have the disadvantage of a large pressure drop (as high as 28 inches water gauge in one case) for efficient collection of fine particles. Also, a wet fly ash slurry must be handled. Scaling, corrosion, piugging, and mist entrainment have proven troublesome.

At the present time, there are only 13 electric utility boilers in the U.S. that operate wet scrubbers for fly ash removal alone. Operating data are therefore somewhat limited. However, some recent data from the Cherokee Power Station using a turbulent contact absorber (TCA) indicate a minimum collection efficiency at a particle diameter of $0.5 \mu \mathrm{m}$ and an overall removal cfficiency of $95 \%$. This does not compare well with the $99 \%$ or gieater. efficiencies obtained with both ESP and filters.

Likewise, it is difficult to quote representative cost figures since the existing installations are on fairly sulall ( $<225 \mathrm{MWe}$ ) units and vary considerably in scrubber type. Moreover, operating problems such as those due to scaling and plugging have in many cases reduced scrubber availability to such marginal levels that utilities are definitely tending toward fabric filters or ESP for new installations.

For the future, there are several advanced concepts under development which may alter the particulate collection picture. These include:

1. Precharging of high-resistivity particles using special sections ahead of conventional ESP units. 
2. The use of electrostatic forces (charged droplets) to improve the performance of wet scrubbers.

3. Wet electrostatic precipitators.

4. Gravel-bed filtration.

Increased attention is also being given to sampling and measurement techniques used in evaluating particulate control devices. No completely satisfactory techniques exist at this time for all of the varied environments that are encountered.

\section{3 NITROGEN OXIDES CONTROL}

In the discussion to this point, sulfur oxide and particulate control technologies have received all of the attention. This is indeed appropriate, inasmuch as they have also occupied center stage in the regulatory and utility sectors. However, it was noted in Chapter 2 that increasing emphasis is being placed on the regulation of nitrogen oxides emissions for stationary sources, and in response several technological options are being developed for their limitation.

N1trogen oxides $\left(\mathrm{NO}_{x}\right)$ are currently emitted in the United States at a rate in excess of 20 million tons per year, of which $32.5 \%$ originate in coalfired utility boilers. These oxides are predominately in the form of nitric oxide (NO) at the point of emission, but this is rapidly converted to the toxic nitrogen dioxide $\left(\mathrm{NU}_{2}\right)$ torm in the atmosphere. 'l'here is no currently available coal fuel option for the control of $\mathrm{NO}_{\mathrm{x}}$, but modification of combustion conditions and flue gas treatment have both been applied to $\mathrm{NO}_{\mathrm{x}}$ control with some success.

In order to properly 1mplement a combustion control plan, it is first necessary to understand the mechanisms by which $\mathrm{NO}_{\mathbf{x}}$ is formed. The details are still topics of active investigation, but it is generally accepted that the oxides are formed in two ways: (1) fixation of molecular nitrogen in combustion air at high (greater than $3300^{\circ} \mathrm{F}$ ) flame temperatures (thermal $\mathrm{NO}_{\mathrm{X}}$ ), and (2) the oxidation of chemically bound nitrogen in the fuel (fuel $\mathrm{NO}_{\mathrm{x}}$ ). The relative contributions from the two mechanisms depend on the fuel composition as well as the combustor design and operating conditions. Some of the major factors involved are:

1. Combustion temperature. The rate of thermal $\mathrm{NO}_{\mathbf{x}}$ formation is highly dependent upon the peak combustion temperatures, 
becoming significant ( $>50 \mathrm{ppm})$ only at temperatures greater than $3300^{\circ} \mathrm{F}$ and doubling for every increase in flame temperature of $70^{\circ} \mathrm{F}$.

2. Air/coal ratio. The formation of both thermal and fuel $\mathrm{NO}_{x}$ is dependent upon the amount of air supplied with the coal; higher air/coal ratios favor higher $\mathrm{NO}_{\mathrm{x}}$ production.

3. Heat release and removal. Low heat-release rates and high heat-removal rates reduce thermal $\mathrm{NO}_{\mathbf{x}}$ formation because low peak temperatures and shorter residence times at high temperatures are achieved.

4. Mixing of fuel, air and combustion products. Distribution of the fuel and air so as to achieve most of the combustion under fuel-rich conditions reduces both fuel and thermal $\mathrm{NO}_{\mathrm{X}}$ formation. Slow diffusion of the fuel and air streams also reduces total $\mathrm{NO}_{\mathbf{x}}$ production. Internal recirculation, or backmixing of combustion products into the primary combustion zone, dilutes both the fuel and air, lowers the flame temperature, and thereby results in less $\mathrm{NO}_{\mathbf{x}}$ formation.

5. Fuel nitrogen content. The nitrogen content of most U.S. coals ranges from one to two percent by weight. The higher the nitrogen content, the greater will be the $\mathrm{NO}_{\mathbf{x}}$ production. The percentage of conversion, however, decreases with increasing nitrogen content. For a given nitrogen content, the amount of $\mathrm{NO}_{x}$ formed per million Btu increases as the heating value of the coal decreases.

The combustion modification approaches to $\mathrm{NO}_{\mathbf{x}}$ control are based on controlling combustion temperatures and oxygen availability. Current methods include low excess air (LEA) firing, staged combustion, flue gas recirculation (FGR), and new burner designs. Table 4.2 summarizes some of the pertinent information regarding these techniques. There are other techniques under development, but these show the most promise for combined fuel and thermal $\mathrm{NO}_{\mathbf{x}}$ control.

Low excess air firing is one of the most widely applied techniques. Field studies have shown that if the excess air is reduced by $10 \%$ (e.g., to $15 \%$ from 25\%), NOx emissions will generally be reduced about $20 \%$. The lowest level of excess air at which a combustion process will operate without unacceptable adverse effects is highly dependent on the boiler type and coal characteristics.

In staged combustion, advantage is taken of both low flame temperatures and low oxygen concentrations. The primary flame zone is kept fuel rich and cooled through radiative heat transfer before combustion is completed with 
Table 4.2 Summary of Combustion Modification Techniques for Contro1 of $\mathrm{NO}_{\mathrm{x}}$ Emissions from Coal-Fired Utility Boilers ${ }^{\mathrm{a}}$

\begin{tabular}{|c|c|c|c|c|c|}
\hline Technique & $\begin{array}{l}\text { Principle of } \\
\text { oneration }\end{array}$ & $\begin{array}{l}\mathrm{NO}_{\mathrm{x}} \text { Emi:ssion Level } \\
\mathrm{NO}_{2} \text { basis, } 3 \% \mathrm{O}_{2} \mathrm{~b}\end{array}$ & $\begin{array}{l}\text { NO } \text { Control } \\
\text { Effectiveness } c\end{array}$ & Linitaticns & Applications \\
\hline $\begin{array}{l}\text { Low Excess Ai= Firing } \\
\text { (LEA) }\end{array}$ & $\begin{array}{l}\text { Eeduces oxygen level } \\
\text { in primary flame } \\
\text { zone and suppresses } \\
\text { tinernal and fuel } \mathrm{No} x\end{array}$ & $\begin{array}{l}\text { Wall firing } \\
45 \text { J } 600 \mathrm{ppm} \\
\text { Tangential } \\
353-450 \mathrm{ppm}\end{array}$ & 20 to $30 \% d$ & $\begin{array}{l}\text { Viburred hyarocarbons; } \\
\text { C) emission: at low } \\
\text { lerel oz exaess air; } \\
\text { increased fouling }\end{array}$ & $\begin{array}{l}\text { Routine use in } \\
\text { utility boilers }\end{array}$ \\
\hline $\begin{array}{l}\text { Staged Combustion } \\
\text { (SC) }\end{array}$ & 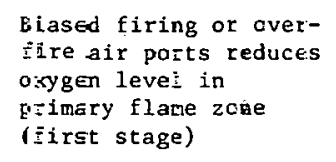 & $\begin{array}{l}\text { Wal1 fising } \\
\text { 35:-450 ppm } \\
\text { Tangential } \\
\text { 25:J-3jC ppm }\end{array}$ & 30 to $45 \%$ & $\begin{array}{l}\text { Fonlirg of convective } \\
\text { section; poor first stage } \\
\text { ignition; soot formation; } \\
\text { load reduct:ton }\end{array}$ & $\begin{array}{l}\text { Retrofit of exist- } \\
\text { ing boilers and } \\
\text { design of new units }\end{array}$ \\
\hline LEA Plus SC & $\begin{array}{l}\text { Combimation of the } \\
\text { above two }\end{array}$ & $\begin{array}{l}\text { Wall fi=ing } \\
\begin{array}{l}350-400 \mathrm{ppm} \\
\text { Tang=ntial } \\
25]-300 \mathrm{ppm}\end{array}\end{array}$ & 40 to $50 \%$ & $\begin{array}{l}\text { Linitatiors with SC plus } \\
\text { corrosion on wall tubes }\end{array}$ & $\begin{array}{l}\text { Retrofit of exist- } \\
\text { ing boilers and } \\
\text { design of new units }\end{array}$ \\
\hline $\begin{array}{c}\text { Flue Gas Recircula- } \\
\text { tion (FGR) } \\
.\end{array}$ & $\begin{array}{l}\text { Eecycled flue gas } \\
\text { reduces the tempera- } \\
\text { tare and oxpgen } \\
\text { concentration of } \\
\text { f:-ame zone }\end{array}$ & $\begin{array}{l}\text { Wall fizing } \\
50 \text { in } 700 \text { ppin }\end{array}$ & 10 to $20 \%$ & $\begin{array}{l}\text { Linited ef fectiveness in } \\
\text { coal-firec boilers }\end{array}$ & $\begin{array}{l}\text { Vone expected for } \\
\text { coal-fired boilers }\end{array}$ \\
\hline
\end{tabular}

${ }^{a}$ The New Source Performance standard fer NOy emissions by eoa-fired itility boilers is 0.7 lb No per nillior. Et of heat input, which corresponds to an $\mathrm{NO}_{2}$ cor.centration of ' -525 ' ppm.

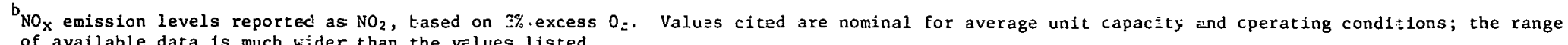
of available data is much wider than the velues listed.

Expressed as functional reciaction relative to taseline No enission levels of 500-900 ppm for wall-fired utility joilers and 400-600 ppm for tangential-f $=$ red hoilers.

d For reduction: of 10 to $15 \%$ in excess $a$ ir. 
the remaining combustion air. This technique may reduce emission of $\mathrm{NO}_{\mathbf{x}}$ by up to $45 \%$, but limitations are imposed by poor flame stability, convective section fouling, excessive formation of unburned hydrocarbons, and boiler tube corrosion. Nevertheless, staged combustion has been regarded as the most successful method for $\mathrm{NO}_{\mathrm{x}}$ control.

Flue gas recirculation is considered less effective for $\mathrm{NO}_{\mathrm{x}}$ control than the preceding two, and high installation costs and energy requirements make it generally unsuitable for coal-fired boilers. Briefly, this technique consists of recycling flue gases back to the combustion zone, thereby reducing both the flame temperature and available oxygen.

For new installations, the potential for significant $\mathrm{NO}_{\mathrm{x}}$ reductions by modified burner designs has been proven both in full-scale and experimental installations. In these burners, the basic principles underlying staged combustion and FGR are incorporated internally in the furnace. This will probably be the preferred approach in the long run as older units are replaced.

The costs for $\mathrm{NO}_{\mathrm{x}}$ control are generally quite low compared to those for $\mathrm{SO}_{\mathrm{x}}$ and particulates. Results from two recent studies can be summarized as follows:

1. LEA firing and overfire air systems (staged combustion) are the lowest cost methods for reducing $\mathrm{NO}_{\mathbf{x}}$ emission levels on both new and existing units. For a 500-MWe utility boiler, the former results in an additional capital cost of $0.55 \$ / \mathrm{kWe}$ (in 1974 dollars) for an existing unit. The additional capital costs for the latter method are $0.50 \$ / \mathrm{kWe}$ (in 1973 dollars) for an existing unit and $0.14 \$ / k W e$ for a new unit. There is no significant operating cost (less than $0.01 \mathrm{mills} / \mathrm{kWe}$ ) for either of these methods.

2. FGR either to the windbox (secondary air) or to the coal pulverlzer (primary air) requires greater capital expenditures than either LEA firing or overfire air, and also increases operating costs because of additional fan power required. In existing units the necessity to reduce unit capacity to maintain acceptable gas velocities could result in a $10-20 \%$ decrease in plant capacity.

3. In general, the capital cost of any of the control methods for an existing unit is approximately twice that for a new unit design.

In the event that sufficient $\mathrm{NO}_{\mathrm{x}}$ suppression cannot be achieved through combustion modifications, the possibilities of various flue gas treatment 
processes are being explored. In general, they can be grouped into four broad classes.

1. Chemical absorption, involving oxidation of $\mathrm{NO}_{\mathrm{x}}$ to $\mathrm{NO}_{2}$, followed by scrubbing with an aqueous acid or alkaline solution to remove the $\mathrm{NO}_{2}$.

2. Physical adsorption, involving removal of $\mathrm{NO}_{\mathrm{x}}$ by solids such as char or copper oxide.

3. Catalytic processes, including decomposition of $\mathrm{NO}_{\mathrm{x}}$, selective reduction of $\mathrm{NO}_{x}$ by $\mathrm{NH}_{3}$, and simultaneous removal of $\mathrm{NO}_{\mathrm{x}}$ and $\mathrm{SO}_{\mathrm{x}}$.

4. Non-catalytic processes, principally selective reduction of $\mathrm{NO}_{x}$ to $\mathrm{N}_{2}$ by $\mathrm{NH}_{3}$ or other reducing agents.

Several of the more promising processes are:

1. The She11/UOP CuO adsurptlun prucess, In addicton ro removing $\mathrm{SO}_{2}$, has been found to remove approximately 60$70 \%$ of the $\mathrm{NO}_{x}$ present as well. This process is being commercially applied on a 40-MWe, oil-fired boiler in Japan, and is being tried in the U.S. on a test flue gas stream corresponding to that of a $0.6-\mathrm{MWe}$, coal-fired boiler.

2. The Bergbau-Forschung/Foster Wheeler process utilizes a char adsorption system for simultaneous removal of $\mathrm{SO}_{2}$ and about $50 \%$ of the $\mathrm{NO}_{\mathrm{x}}$. A pilot plant add-on unit (coal-fired boiler) was in operation in West Germany from 1968 to 1970. A demonstration unit has been built for Gulf Power Company in Chattahoochee, Florida. After a hrief perind nf nperation the test program was indefinitely postponed.

3. In the Chiyoda Thoroughbred 102 process both $\mathrm{SO}_{\mathrm{x}}$ and $\mathrm{NO}_{\mathbf{x}}$ are removed after the $\mathrm{NO}_{\mathbf{x}}$ is oxidized to $\mathrm{NO}_{2}$ with ozone in an absorber containing an aqueous sodium sulfite solution. A similar process by Fuji Kasui uses chlorine dioxide instead of ozone for the oxidation step. $\mathrm{NO}_{x}$ removal levels of $60-90 \%$ appear possible with these processes.

4. The Kawasaki Magnesium process uses magnesium scrubbing and limc addieion for simultaneous remuval of $30_{x}$ and $\mathrm{NO}_{x}$. A pilot plant with a capacity of treating fluc gao from a ?1.7 MWe, coal-fired boiler has been operated in Japan since 1975.

5. The Exxon Thermal DeNO $\mathrm{x}_{\mathrm{x}}$ process uses $\mathrm{NH}_{3}$ at 1300 to $1900^{\circ} \mathrm{F}$ to selectively reduce about $70 \%$ of the $\mathrm{NO}_{\mathrm{x}}$. This process has been demonstrated in Japan on full-scale, gas- and oilfired boilers, but no information on coal-fired boilers is currently available. 
In general, the costs of these processes appear comparable to those for FGD, which are at least a factor of 10 higher than the costs of combus tion modification techniques. Consequently, these processes are expected to find little use in the United States unless and until the $\mathrm{NO}_{\mathrm{x}}$ emission regulations are made considerably more stringent.

\section{4 SOLID WASTE DISPOSAL}

If $\mathrm{NO}_{\mathbf{x}}$ control can be achieved through combustion modifications, no additional contribution will be made to the solid waste disposal problem. This is just as well, since the combination of ash and FGD scrubber sludge may severely tax the waste-handling capabilities of power plants, as noted previously, and may also pose environmental problems of a chemical nature.

'l'he disposal of the unused ash involves potential problems of pollution of surface and subsurface water. The ash consists chiefly of the oxides of silicon, aluminum, and iron, but most of the trace elements present in the coal are also present in the ash. In a recent investigation of leachates from a number of ash ponds, it was found that concentrations of $\mathrm{As}, \mathrm{Ba}, \mathrm{B}, \mathrm{Cr}, \mathrm{Hg}$, Mo, and Se exceeded one or more of the water quality criteria at one or more of the power plants, sometimes by an order of magnitude. The leachability of various species in the ash will be determined largely by solubility, with about $2-5 \%$ of the fly ash being soluble in water. The resulting solution is usually alkaline due to the presence of free lime, but some ashes from eastern coals produce acid leachates. In these acidic liquors, concentrations of sulfate, iron, zinc, lead, cadmium, and maganese often exceed criteria for discharge into streams. Attenuation of the leachate contents by percolation through soil is expected in many cases to provide substantial protection against trace elements reaching an aquifer, but disposal sites will need to be monitored and controlled.

The potential for contamination of groundwater by leachates can be reduced by preventing or diverting flows of surface and subsurface waters (e.g., by maintaining a suitable system of subsurface and trench drains). Protection against erosion and liquefaction can be achieved by good compaction, proper drainage, and development of a suitable vegetative cover.

Ilowever, ash does not readily support most plant growth. This is due partly to the lack of necessary nutrients and partly to the presence of 
toxins. Boron, in particular, may be 20 times as available in fresh ash as in normal soil. Fortunately, several plant spectes have been identified as tolerant of ash conditions. These include some grasses and members of the beet and cabbage families.

Thus, it seems reasonable to conclude at this time that, while disposal of ash continues to pose an environmental problem, the problem is not much worse than other waste disposal situations and is one that can be managed by careful monitoring and by optimum employment of currently available. technology.

The problems involved in the disposal of wastes from lime or limestone scrubbing (or the double alkali process) are much greater because the crystalline nature of the calcium sulfite hemihdrate makes it impossible to physically dewater the sludges to the extent required to support weight. The sludges can contain varying amounts of $\mathrm{CaSO}_{4}$ and unreacted $\mathrm{CaCO}_{3}$, but the major component in sludges from high sulfur coals is the troublesome sulfite. The sludges can also contain varying amounts of fly ash, from a few percent when particulates are collected dry prior to scrubbing up to the total weight of fly ash when collection is incorporated with the FGD process. The behavior of representative sludges in ponding and in vacuum filtration is shown in Table 4.3. It may be noted that the solids content of high sulfite sludges increases with ash content but not enough to permit compaction. For

Table 4.3 Comparison of Typical Sludge Dewatering Properties

Appiouxillide Degres of Dewatering, percent solids

\begin{tabular}{|c|c|c|c|}
\hline \multirow[b]{2}{*}{ Sludge Type } & & \multirow[b]{2}{*}{$\begin{array}{c}\text { Approximate Percent } \\
\text { Solids for } \\
\text { Optimum Compaction }\end{array}$} \\
\hline & Settling & Filtration & \\
\hline $\begin{array}{l}\mathrm{High} \mathrm{CaSO}_{3} \cdot 1 / 2 \mathrm{H}_{2} \mathrm{O} \\
(\text { low fly ash })\end{array}$ & $30-35$ & 50 & 80 \\
\hline $\begin{array}{l}\mathrm{High} \mathrm{CaSO}_{3} \cdot 1 / 2 \mathrm{H}_{2} \mathrm{O} \\
\text { (high fly ash) }\end{array}$ & $35-40$ & $55-60$ & 80 \\
\hline $\begin{array}{l}\mathrm{High} \mathrm{CaSO}_{4} \cdot 2 \mathrm{H}_{2} \mathrm{O} \\
(\text { low fly ash })\end{array}$ & $60-65$ & 80 & 90 \\
\hline
\end{tabular}


this reason, separately collected fly ash has usually been combined with scrubber slurries before ponding, dewatering by centrifugation, or vacuum filtration.

The ponding of such mixtures presents many problems. The permeability of the mixtures is low $\left(10^{-4} \mathrm{~cm} / \mathrm{sec}, 100 \mathrm{ft} / \mathrm{yr}\right)$ and problems arising from the leaching of trace elements will be similar to those encountered in disposal of fly ash alone. Samples of scrubber wastes have been found to contain various trace metals ( $\mathrm{As}, \mathrm{Cd}, \mathrm{Cr}, \mathrm{Pb}, \mathrm{Hg}$, and $\mathrm{Se}$ ) in amounts exceeding $\mathrm{EPA}$ Proposed Public Water Supply Intake Criteria. $\mathrm{Hg}$ and Se exceeded the criteria by more than an order of magnitude in every case. Leaching of the calcium solids can give rise to excessive oxygen demand and total dissolved solids. An impervious liner of clay, cement, or synthetics will therefore be required for the pond. Capital costs for such liners can range from $\$ 5 / \mathrm{kW}$ for clay up to $\$ 40 / \mathrm{kW}$ for $47-\mathrm{mil}$, doubly-reinfcrced plastic.

An overriding objection to simple ponding of the sludges, however, is the fact that reclamation of the land is not possible and large areas of land are permanently withdrawn from use. The weight of dry calcium solids from L/LS FGD of a coal containing $3 \%$ sulfur and $12 \%$ ash is approximately equal to that of the ash. Since the ponded sludge/ash mixtures contain only about $50 \%$ solids, whereas ash ponded alone contains $80 \%$ solids, the area required for disposal of the sludge/ash mixture is more than three times that for the ash alone. It can be anticipated that as more FGD systems come on line that simple ponding will not be permitted, particularly since other options are available or being developed.

Chemical fixation of L/LS sludges is already being carried out at a number of FGD installations. Several proprietary additives are available that can be used to increase the compressive strength and decrease the permeability of sludge/ash mixtures. Quantities of additives corresponding to $5-10 \%$ of the weight of dry calcium solids are sufficient to lead to formation of a low grade concrete from sludges that have been adequately dewatered.

Utilities have also concocted their own fixation recipes, adding a few percent of lime or portland cement and sometimes additional fly ash. In at least one case, the fixed sludge has been certified by EPA for, and actually. used, in a landfill operation. Leaching tests of sludges fixed with proprietary additives and cured have shown premeabilities in the range of $10^{-5}$ to 
$10^{-7} \mathrm{~cm} / \mathrm{sec}$, which is within the limits of acceptability for landfill. One of the more uncertain aspects of FGD economics, however, is the projected cost of fixing, transporting and disposing of the wastes. Better definition of these costs, as well as realistic information on the cap1tal and operating costs of regenerable FGD processes, are needed to determine the proper direction for further developmental efforts on FGD.

An alternative approach to waste disposal that is actively being investigated and shows promise involves oxidation of the spent (ash-free) scrubber liquor to convert the calcium sulfite to calcium sulfate. Since gypsum can be satisfactorily dewatered and disposed of, environmental problems would be eliminated if complete oxidation can be achieved. It has been shown possible to grow Kentucky 31 grass. In a forcibly oxidized limestone sludge by adding only fertilizer and water.

\subsection{WASTEWATER CONTROL}

Processes such as dewatering must also be considered in light of the wastewater treatment and disposal problems they aggravate or create. These are part of the overall wastewater control picture that is receiving increasing scrutiny in many quarters as it is related to power plant operation. One result is a shift in emphasis from once-through water systems to water recycle.

For purpocco of this rcport, liquid effluents can be divided into three categories: (1) blowdown and equipment cleaning waste, (2) solids handling water, and (3) coal cleaning and conversion process water. Characterization of these effluents is the topic of several current studies, but the available data show that the waste streams can be highly variable, making treatment problems site and plant specific. Cooling tower blowdown water typically contains high concentrations of suspended and dissolved solids, and sometimes significant amounts of residual chlorine. Chromium, zinc, phosphate, or other corrosion inhibitors and biocides may also be found. The best available treatment is lime-soda softening followed by reuse as makeup water. Boiler blowdown can be treated similarly.

Equipment cleaning waste originates mainly from boiler and boiler tube cleaning, and contains high levels of toxic chemicals. It appears that the necessary treatment steps will include $\mathrm{pH}$ adjustment, precipitation, sedimentation, filtration, ion exchange or reverse osmosis, and ammonia removal. 
Solids handing water includes that used to sluice fly ash to settling ponds. The main problems with ash pond effluents are suspended solids and trace elements combined with large variations in $\mathrm{pH}$. Treatment methods will have a high degree of site specificity depending principally on the pH range. It is likely that this water will have to be recycled to meet the 1983 BATEA requirements.

Coal cleaning and preparation techniques produce effluents high in suspended solids and trace metals. The majority of these processes are using recirculating water systems with treatment by thickeners, filters, or sett1ing ponds in the cycle. Specific information on coal preparation is given in Chapter 3 of this report. 


\section{ADVANCED SYSTEMS}

The problem of compliance with environmental standards in a costeffective manner has spawned a number of technological developments other than those already discussed in this report. None of these can be considered commercially available, but enough experimental and pilot-plant work has been done for preliminary estimates to be made of their potential usefulness. In its initial year, the Argonne ECT program has begun Investigations of two such technologies -- fluidized-bed combustion (FBC) and advanced coal preparation techniques.

\subsection{FLUIDIZED BED COMBUSTION}

Fluidization is a widely used technique for carrying out heat and mass transfer operations in chemical processes involving pulverized solid materials. As applied to coal combustion, it permits high energy utilization efficiency and high rates of heat delivery at relatively low temperatures of combustion.

A fluidized bed is a volume of solid particles held in suspension in an upward flowing air stream. The velocity of the flowing air stream required to suspend the particles is a function of the particle density and size. Because of the turbulent movement of the particles, the gas-solid mixture behaves like a fluid and the heat transfer between the particles is very rapid. This results in a temperature distribution in the bed that is essentially uniform and enhances the heat transfer process. When coal is burned in a fluidized bed, the heat released is transferred to the rapidiy moving particles and thence to the steam generation tubes located inside the combustor. The steam produced in the tubes is used to generate electricity in a conventional steam turbine plant.

Three different types of FBC are usually considered: (1) the atmospheric fluidized-bed combustor ( $A F B C)$, (2) the pressurized fluidized-bed combustor ( $P F B C)$, and (3) the adiabatic combustor. Schematic diagrams of the three types are shown in Fig. 5.1.

In an $A F B C$, coal is burned at atmospheric pressure in a bed of pulverized dolomite or limestone. Most of the sulfur dioxide $\left(\mathrm{SO}_{2}\right)$ formed during burning of the coal is absorbed by the limestone or dolomite to form 
ATMOSPHERIC FLUIOIZED BED COMBUSTION (I AIm, 15-25\% Excens Air)

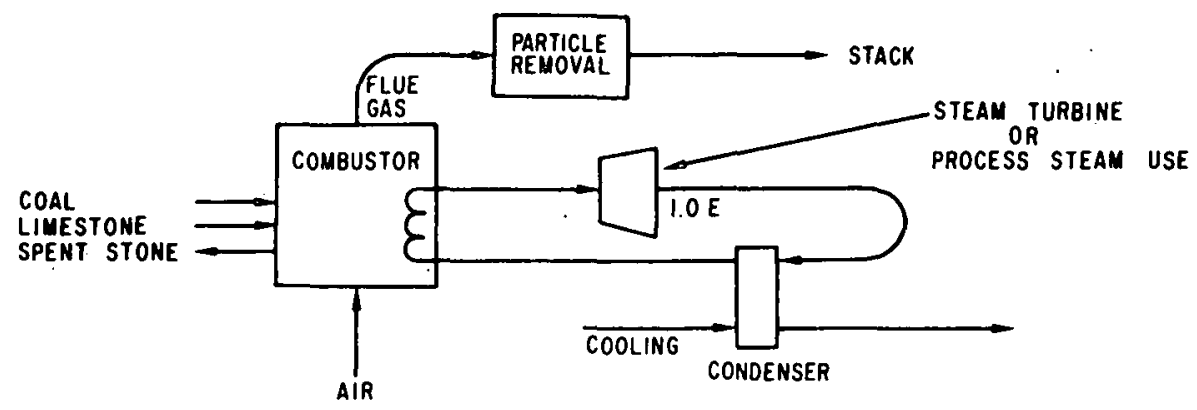

PRESSURIZED FLUIDIZED BED COMBUSTION (10 Atm, 15-25\% Excess Air)

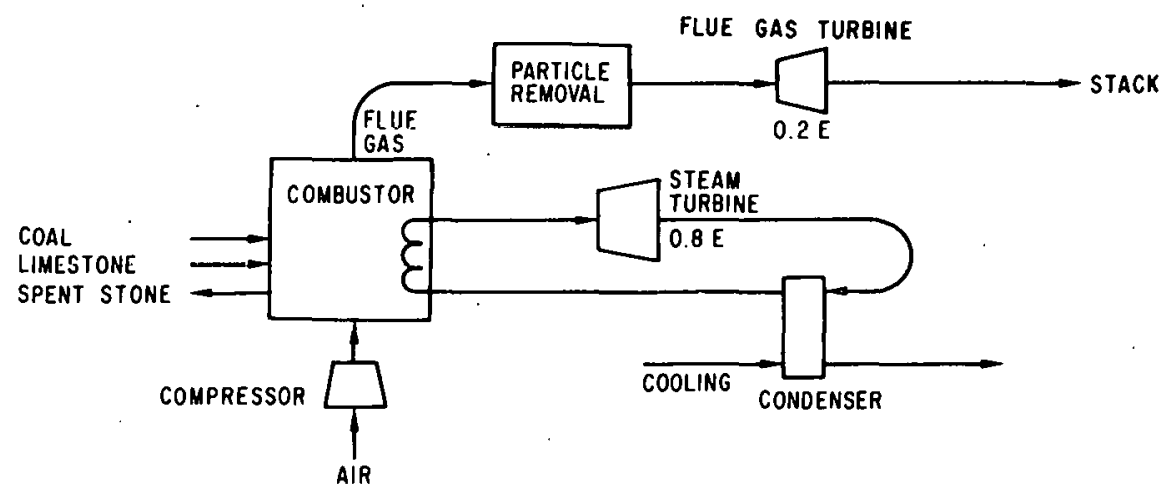

PRESSURIZED ADIABATIC FLUIDIZEO BED COMBUSTION (10 ATm, $300 \%$ Excess Air)

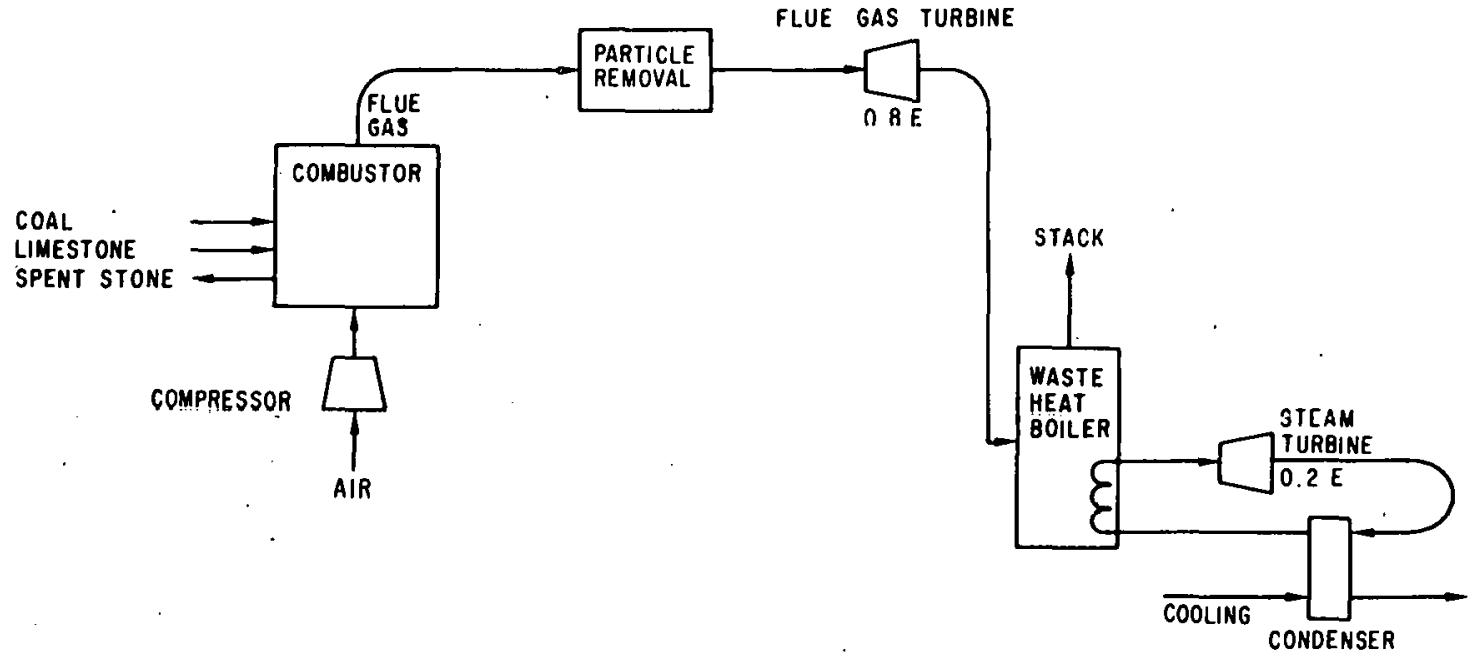

Fig. 5.1 Schematic Diagram of the Three Fluidized-Bed Combustion systems Showing the General Energy-Conversion Cycles 
solid calcium sulfate, which is withdrawn from the combustor separately from the coal ash. To replace the spent sorbent, fresh limestone or dolomite is continuously added to the bed.

The PFBC concept differs basically in that it operates normally at about 10 atmospheres and requires the use of dolomite for proper $\mathrm{SO}_{\mathrm{x}}$ removal (1imestone does not react properly at these pressures). Because the fluidizing gas is at an elevated temperature and pressure, it is desirable to recover. the energy in the gas in order to take full advantage of the coal combustion energy and thereby increase the total system efficiency. To accomplish this, the hot gas must be cleaned of particulates and expanded through a turbine to atmospheric pressure before release to the stack. About $20-25 \%$ of the electrical energy generated by a PFBC is produced in the gas turbine. Overall, a small but definite improvement in combustion efficiency is expected for the PFBC as compared to the AFBC.

Another advantage is that the PFBC is smaller than an $\dot{A F B C}$ of the same power. This permits shop fabrication and field assembly of the boiler, as opposed to the field construction generally anticipated for an AFBC. Shop fabrication should result in a lower capital cost for a given installed capacity.

If the rate of air throughput is increased to the point where essentially all of the heat of combustion is removed by the fluidizing gas, the reactor is said to be operating as an adiabatic combustor. This eliminates the need for heat transfer tubes in the combustor bed, since the gas can be used to drive a turbine directly and additional energy can be obtained from the turbine exhaust gases using a boiler and steam turbine.

The primary motivation for developing FBC as a heat source for clcctricity generation is the promise it offers for more economic control of air pollutants. No large-scale operating data are available as yet, but extrapolations of results obtained with bench- and pilot-scale fluidized-bed combustion facilities indicate a high probability that commercial coal-fired electric utility plants employing fluidized-bed combustors of either the atmospheric or pressurized type will easily comply with the present federal standards for emission of sulfur dioxide and nitrogen oxides, regardless of the rank or type of coal being burned, and without the necessity for coal cleaning or stack-gas scrubbing. 
As noted previously, control of $\mathrm{SO}_{2}$ emission is achieved by adding to the bed, along with the coal, appropriate (and quite feasible) amounts of ground limestone or dolomite. The calcium in this stone combines chemically with $\mathrm{SO}_{2}$ and excess oxygen in the combustion gases to form calcium sulfate, which is a stable solid under the conditions in the bed. In this way, as much as $90 \%$ of the sulfur contained in the coal can be retained in the bed, even when burning high-sulfur coal.

The nitrogen oxide content of the flue gas from a fluidized-bed combustor has been found to be significantly less than that of a conventional pulverized-coal-fired plant. This lower value may in part be due to the lower temperature of operation of the fluidized-bed combustor. In a pulverizedcoal-fired plant temperatures as high as $3000^{\circ} \mathrm{F}$ may be reached, whereas a fluidized-bed combustor operates at $1500-1700^{\circ} \mathrm{F}$.

Present federal standards for $\mathrm{NO}_{\mathrm{x}}$ emission from new, coal-fired electric utility plants correspond to an $\mathrm{NO}_{x}$ concentration of $2525 \mathrm{ppm}$ in the stack gas. It is expected that plants employing atmospheric-pressure, fluidized-bed combustors will give $\mathrm{NO}_{\mathbf{x}}$ emission levels in the range of 250$450 \mathrm{ppm}$, while combined-cycle plants with pressurized fluidized-bed combustors should give $\mathrm{NO}_{\mathrm{X}}$ emission levels in the range of $100-200 \mathrm{ppm}$.

The federal standard for particulate emissions from new, coal-fired electric utility plants corresponds to a particulate loading of approximately $0.05 \mathrm{gr} / \mathrm{scf}$ in the stack gas. Tests made with bench- and pilot-scale fluidized-bed combustors have shown loadings of at least 100 times that value in the offgas from the combustor. Nevertheless, experimental results indicate that the loading can be reduced to an environmentally acceptable level by the use of conventional particulate collection devices such as cyclones and baghouses. The effectiveness of electrostatic precipitators for this particular application seems questionable, owing to the unusually high electrical resistivity of the particles.

In plants where the hot offgas from a pressurized fluidized-bed combustor is used to drive a gas turbine, requirements for particulate removal to avoid excessive erosion and loading of the turbine blades will be even more stringent than would be needed just to satisfy the environmental emission standards. Although it is not yet entirely clear how these requirements can be met, advanced types of cyclones and filters intended for high- 
temperature operation are being developed and show promise of being capable of meeting the challenge.

The situation as regards trace elements and hydrocarbons in the effluents is still highly uncertain. Based on those few experimental studies which have been reported, it can be at least tentatively. concluded that coalfired power plants employing fluidized-bed combustors will in general produce lower levels of trace-element emissions than plants employing conventional combustors. This is attributable, at least in part, to the lower combustion temperatures in fluidized-bed combustors, and possibly also to the presence of limestone or dolomite in the bed. There is also experimental evidence indicating that the lower combustion temperatures are effective in reducing the preferential concentration of trace elements in the finer fly-ash particles that has been observed in conventional coal-fired plants.

of particular concern among hydrocarbon emissions are the so-called polycyclic aromatic hydrocarbons, inasmuch as some of these compounds, such as benz(a)pyrene, are known carcinogens. The relative rates of formation and decomposition of such compounds during the burning of coal are strongly dependent upon combustion conditions. Conditions leading to relatively low combustion temperatures, as is the case in fluidized-bed combustors, are especially suspect, since it is believed that compounds such as benz(a)pyrene may form more rapidly than they decompose at combustion temperatures of $13 U U$ $1700^{\circ} \mathrm{F}$. It should be emphasized, however, that there is virtually no experimental information available at this time concerning the presence or concentration levels of such organic compounds in the emissions from fluidized-bed combustors.

Pollutants other than those discharged to the atmosphere must also be controlled. It is believed that the impacts resulting from transportation, storage, handling, and preparation of coal and stone, from cooling operations and waste-heat disposal, and from water usage and discharge at FBC power plants can be accomplished by standard industrial practices such as are now used at conventional coal-fired plants. However, FBC plants will probably produce large quantities of spent stone sorbent which must be disposed of in an environmentally sound manner. Regeneration of the stone could reduce the disposal task, but the technical and economic feasibility of such a process is still quite questionable. 
In contrast to $\mathrm{SO}_{\mathrm{x}}$ scrubber sludge, the $\mathrm{FBC}$ discharge is a dry, particulate solid composed mainly of coal ash, $\mathrm{CaSO}_{4}, \mathrm{CaO}, \mathrm{CaCO}_{3}$, and (when dolomite is used) $\mathrm{MgO}$. Owing to the absence of $\mathrm{CaSO}_{3}$, it is not expected to show the undesireable thixotropic properties of wet scrubber sludge.

Disposal of the spent sorbent by landfill is an obvious choice, and preliminary studies indicate that such a course of action would probably not cause significant water, heat, or air pollution. However, the properties of the sorbent may be expected to vary with different combustor operating conditions, and the potential leaching problem is highly site specific. Also, leaching tests have shown that the leachate may have a high $\mathrm{pH}$. Thus, this area requires further study before any firm conclusions can be reached.

Numerous other disposal options are being investigated. These include:

1. Use as an agricultural fertilizer and soil conditioner.

2. Use as a gypsum substitute in the manufacture of wal1board and other products.

3. Use as filler material in the manufacture of cement and cinder blocks and for roadbed construction.

of the alternatives cited, the agricultural uses appear to have the most economic promise, although competition from natural sources of gypsum could limit the sorbent market in many areas.

At the other end of the system, sorbent supply should pose no problems. The U.S. has excellent reserves of limestone and dolomite, and production facilities are well developed. If any shortages appear, they can be expected to be of a local nature arising from the logistics of transportation.

It must be borne in mind, however, that all conclusions regarding commercial FBC use are very tentative at this time. The bulk of the operating experience to date has been with laboratory and development units concerned primarily with combustor operation rather than electricity generation. However, the 30-MWe Rivesville AFBC plant is now in the testing stage, and can be expected to provide valuable jnformation when it goes into full operation. Although its output is quite modest by today's power plant standards, the disparity with commercial FBC units is not as great as one might suppose. Large FBC plants will probably be composed of a number of modules, giving flexibility in both size and operation (e.g., turn-down capability and maintenance). 
Commercial availability of large-scale AFBC plants is projected for the mid-1980s. The costs are expected to be competitive with conventional boilers utilizing FGD. The PFBC concept is not expected to reach full commercial status until the mid-1990s.

\section{$5.2 \cdot$ ADVANCED COAL PREPARATION}

The other area of advanced technology that has been reviewed by this project is advanced coal preparation. A large number of techniques are under active investigation, but none has reached full commercialization and few have been evaluated at even a small pilot-plant level. They may be roughly divided into physical and chemical separation methods, and most of them are concerned primarily with sulfur reduction.

Physical processes achieve sulfur reductions through fine pulverization and density separation of pyrite particles. New or improved techniques based on gravity include:

1. Humphrey spiral.

2. Pinched sluice (wet).

3. Pinched sluice (dry).

4. Mliaking Lables.

5. Fine-coal jigs.

The use of Induced particle charges (electrophoresis) for separation of coal from pyrite and silica has been studied, but was deemed uneconomical. Other electrostatic procedures seem constrained by the need for moisture control, close sizing requirements, and capacity limitations.

Magnetic separation of pyrites is possible, but very intense fields are required. Methods for increasing the magnetic response of pyrite are being investigated, and some progress has been made.

Other physical processes for sulfur reduction include:

1. Two-stage froth flotation.

2. Leeds flotation column.

3. Selective slimes flocculation.

4. 0il agglomeration.

Moisture control is another aspect of physical processing which is of increasing importance as particle sizes are reduced. New or improved 
techniques include:

1. High frequency vibrating screens.

2. Centrifuges.

3. Vacuum filters.

4. Static thickeners.

5. Refuse combustion.

Chemical treatment processes must be used to remove organic sulfur from coal, as well as the finely dispersed pyrites and mineral matter that cannot be removed completely or efficiently by physical separation. These processes are generally more involved than current physical separation methods, requiring the use of finer particle sizes, longer residence times, higher temperatures and pressures, special construction materials, and the. need to recover and regenerate chemical solutions. Some of the contending methods under development are listed below:

1. TRW-Meyers process. This is based on the reaction of pyrites with a hot solution of ferric sulfate that oxidizes the pyrites to soluble sulfates and elemental sulfur. Organic sulfur is not removed. An 8-ton per day pilot plant designed to demonstrate crucial parts of the process should come into operation during 1977.

2. Oxygen leaching. Pyrites can be oxidized and converted into sulfuric acid and/or water-soluble sulfates by leaching coal with hot aqueous solutions containing oxygen under pressure. This method offers the potential for removal of organic sulfur. A continuous-flow benchscale system was expected to be in operation before the end of 1976.

3. Battelle hydrothermal process. A hot caustic snlution can be used to leach coal and extract both pyritic and organic sulfur. Trace elements are also reduced and the ash content is lowered in a subsequent ac1d treatment. The process is being tested in a small continuous-flow reactor.

4. Treatment with nitric acid or nitrogen oxides. Pyrite and certain minerals (ash) can be removed from coal by leaching with hot dilute nitric acid. Small scale experiments have been conducted in the USSR. Treatment of coal in a fluidized bed reactor with a hot gas mixture of air and nitrogen oxides has been shown to reduce both pyritic and organic sulfur contents. Development of the process is continuing by KVB Engineering, Inc.

5. Combined physical and chemical cleaning. A pilot-plant operation in the USSR demonstrated (1956-57) that combined heavy media separation and chemical leaching 
with ferric sulfate and nitric acid could remove a large part of the inorganic sulfur and ash from coal. Information on further development is not available.

6. Bacteriological process. The extraction of pyritic sulfur by the action of iron and/or sulfur oxidizing bacterla has been demonstrated in small-scale experiments. The process is relatively slow, but larger-scale experiments are underway to further refine the technique. 


\section{FUTURE PROGRAM EFFORTS AND RECOMMENDATIONS}

During the coming year, this program will be moving forward on a number of fronts. The combustion processes and control technologies covered in this report will be monitored and significant achievements will be analyzed. In addition, certain areas crucial to those technologies will receive the kind of in-depth analyses that have not been possible thus far.

The scope of the program will also be expanded to take in several additional areas of interest. These include production and combustion of solvent refined coal, and the low-Btu gasification of coal with combinedcycle combustion. Both of these technologies appear to show promise for the economic and environmentally acceptable utilization of coal in power generation. The list of potential pollutants under consideration will be enlarged by the addition of studies dealing with the emission and control of the trace elements present in coal.

Another important effort during the coming year will be a comparative evaluation of the various control options. A significant start has already been made in this area by a subcontractor to the ECT project who has scoped out a possible control evaluation and selection procedure, as well as defining the numerous technical parameters required for the process.

In general, the technologies will be broken down into modules which can then be combined to form a variety of different systems. Typical modules would be fuel, fuel pretreatment, combustion, and emission posttreatment. For each module, the factors to be analyzed will include such things as the required input, resource requirements, economic considerations, performance, applicability, environmental consequences, and output characteristics.

While this approach gives great flexibility, it also requires the manipulation of many parameters and very large amounts of data. A computerized data base is planned to facilitate that task. This base will provide the information required by other computer programs which will actually perform the necessary calculations leading to the technological, economic, and environmental output factors for each module. These calculational programs will be developed over a period of time in such a way that the level of sophistication is commensurate with the available data. 
The results of the evaluations should provide insight into the optimum control technology choices under various assumptions regarding location, new or existing capacity, economic climate, and environmental regulations. It is expected that these evaluations will be a continuing component of this program, and that the procedure will be continually developed and refined as experience is gained and more data are accumulated.

In that regard, a paucity of data has already been established in several areas, as noted previously in this report. To alleviate this situation, a number of research and development needs have been identified and summarized below. No attempt has been made to identify priorities.

Hedlth Effects:

- Evaluation of the health effects assoctated witin the release of trace elements, heavy metals, and radionuclides from coal combustion.

- Comparison of the potential health impacts of airborne versus waterborne pollutants, incorporating factors such as environmental sinks, food chains, synergisms, and other factors affecting the biologically effective dose to man.

- Development of quantitative mortality projection models or descriptions for the health impacts of combustion effluents in order to provide a basis for comparing the mitigating effects of various control technologies on public health.

- Preparation of a detailed generir assessment nf alı nf the occupational and public health risks, arising from the complete coal fuel cycle.

Low Sulfur Coal:

- Evaluation of the technical aspects of using low sulfur coal in existing utility boilers designed for midwestern bituminous coal.

- Evaluation of the capital and operating cost differentials for new utility boilers designed for low sulfur western coal as versus those designed for midwestcrn coal.

\section{Coal Preparation:}

- Continuation of studies on the characteristics of U.S. coal seams, particularly with respect to trace elements and coal washability.

- Characterization of runoff and wastewater drainage effluents from preparation facilities.

- Development of improved pollution control technologies for all emissions, including noise, from preparation facilities. 
- Development of improved techniques for the treatment and disposal of fine-coal wastes.

- Development and evaluation of improved fine-coal dewatering, handling, and drying techniques.

- Optimization of process conditions for the various desulfurization methods under development (especially chemical), and assessment of their potentials for extracting nitrogen, trace elements, and mineral impurities.

- Evaluation of the economics and feasibility of employing chemical processing for additional beneficiation after physical cleaning.

Flue Gas Desulfurization:

- Development of flue gas desulfurization (FGD) processes which produce marketable and/or easily disposable end products for conventional power plant combustion systems.

- Development and demonstration of promising regenerable FGD processes.

- Development of techniques for the direct reduction of $\mathrm{SO}_{2}$ with coal.

- Development of technology for the chemical fixation of FGD wastes.

- Development of a cost-effective process for oxidizing FGD solids to produce $\mathrm{CaSO}_{4}$.

- Comparison on economic and environmental grounds of FGD waste disposal alternatives.

Nitrogen Oxides Control:

- Development and demonstration of improved burner designs.

- Systematic and long-term evaluation of corrosion under modified combustion conditions.

- Evaluation of the effect of combustion modification on the emission of other pollutants, such as primary sulfate, trace elements, and hydrocarbon particulates.

- Development of improved methods for removal of $\mathrm{NO}_{\mathrm{x}}$ by flue gas treatment, both by reduction to $\mathrm{N}_{2}$ and by oxidation to $\mathrm{NO}_{2}$ for removal by wet scrubbing.

Particulate Control:

- Development of a particulate size-distribution measurement method applicable to fuel combustion emission sources.

- Development of control technology for removing particulates from high temperature and high pressure gases $\left(1700-2700^{\circ} \mathrm{F}\right.$ and 200 psia). 
- Development of control technology for removal of fine particles ( $<1 \mu \mathrm{m}$ diameter) with an efficiency of over $99 \%$.

- Determination of the ultimate fate of additives used to improve the performance of electrostatic precipitators, and evaluation of their potential for deleterious environmental effects.

Fluidized Bed Combustion:

- Development and demonstration of a feasible sorbent regeneration method.

- Development of synthetic sorbents with improved reactivity, regenerability, and attrition resistance.

- Evaluation of control options for the reduction of $\mathrm{NO}_{\mathbf{x}}$ emissions.

- Determination of the ultimate disposition of trace elements from coal.

- Determination of the chemistry of hydrocarbon emissions, and the effects of temperature and controls on their formation and disposittion,

- Evaluation of potential turbine materials and gas requirements for turbine use.

- Development of particulate removal methods for application to hot gas streams.

- Evaluation of the relationship between operating variables and the cost of electricity. 
Distribution of ANL/ECT-1

Internal:
C. D. Brown (2)
W. L. Buck (2)
L. Burris
E. L. Carls
R. P. Carter
R. R. Cirillo (2)
E. J. Croke
C. D. Dux (2)
A. R. Evans
P. S. Farber (2)
P. R. Fields
J. Fischer
D. Grahn (2)
P. F. Gustafson
L. J. Habegger
L. J. Hoover

\author{
H. S. Huang (2), \\ K. A. Hub \\ D. O. Johnson \\ I. Johnson \\ A. A. Jonke \\ G. C. Krohm (2) \\ M. L. Kyle \\ G. Leppert \\ L. R. Lewis \\ C. D. Livengood (2) \\ R. T. Lundy (2) \\ M. V. Nevitt \\ N. M. O'Fallon \\ A. O. Perry \\ E. G. Pewitt \\ R. D. Pierce
}

G. N. Reddy (2)

J. J. Roberts

M. E. Samsa
N. F. Sather (2)

W. K. Sinclair

A. E. Smith (2)

A. Tevebaugh

J. C. Vankuiken

J. Voge1

S. Vogler (2)

K. E. Wilzbach (211)

S. H. Wong (2)

J. Young

ANL Contract Copy

ANL Libraries (5)

TIS Files (6)

\section{External:}

DOE-TIC, for distribution per UC-90, -90a, $-90 \mathrm{~b},-90 \mathrm{e},-90 i,-90 j$ (333)

Manager, Chicago Operations Office

Chief, Chicago Patent Group

President, Argonne Universities Association

Energy and Environmental Systems Division Review Committee:

T. G. Frangos, Madison, Wis.

J. H. Gibbons, U. Tennessee

W. Hynan, National Coal Association

D. E. Kash, U. Oklahoma

D. M. McAllister, U. California, Los Angeles

L. R. Pomeroy, U. Georgia

G. A. Rohlich, U. Texas at Austin

R. A.: Schmidt, Electric Power Research Inst.

J. W. Winchester, Florida State U.

R. J. Bywater, The Aerospace Corporation

R. C. Corey, U. S. Department of Energy

K. W. Costello, Lyons, IL

T. J. Chu, Tennessee Valley Authority

A. W. Deurbrouck, U. S. Bureau of Mines

C. W. Draffin, Jr., U. S. Department of Energy

C. E. Feazel, Southern Research Institute (2)

E. Fox, Oak Ridge National Laboratory.

J. H. Fox, Trident Engineering, Annapolis, MD

E. Frederick, Air Pollution Control Association, Pittsburgh

B. S. Friedman, Chicago, IL (2)

M. Gottlieb, U. S. Department of Energy (50)

J. Gruh1; Massachusetts Institute of Technology

J. N. Goulias, Illinois Institute for Environmental Quality

J. S. Hartman, PEDCo Environmental

R. J. Helfinstine, Illinois State Geological Survey 
E. C. Holt, Hoffman-Muntner Corporation

R. E. Hucko, U. S. Bureau of Mines

J. D. Kilgroe, U. S. Environmental Protection Agency

A. L. Kernkamp, Michigan State University

T. D. Kolflat, Sargent and Lundy Engineers

J. Leonard, West Virginia University

P. W. Lin, Angola, IN

J. B. Livengood, Office of the Secretary of State, Indiana

H. Lovel1, Pennsylvania State University (2)

R. A. McCallister, Foster Wheeler Energy Corporation

L. C. McCandless, Versar, Inc., Springfield, VA

G. McGlamery, Tennessee Valley Authority

R. W. McIlvaine, McIlvaine Co., Northbrook, IL

P. J. Phillips, New York

J. A. Pryor, Air Products and Chemicals. Inc.

G. L. Robinson, Battelle Columbus Laboratories

M. F. Kuãné, Massachusetts Institute of Technology

E. S. Rubin, Carnegie-Mellon University

F. C. Schweppe, Massachusetts Institute of Technology

H. Shaw, Exxon Research and Engineering

E. Y. Shih, PROCON, Inc.

D. Spencer, Electric Power Research Institute

B. Y. Su, United Engineers and Contractors, Inc.

R. E. Thompson, KVB, Inc.

W. E. Thompson, Research Triangle Institute

S. M. Warren, Jr., Chapel Hill, NC

J. Wendt, U. Arizona

E. M. Wewerka, Los Alamos Scientific Laboratory

T. O. Wheelock, Iowa State University (2)

B. White, Exxon Research and Development

G. Wiens, California Air Resources Board

J. Winnick, U. Missouri, Columbia

K. E. Ycager, Electric Power Research Institute

J. Yu, Bechtel Corporation

E. Zawadzki, McMurray, PA

R. E. Zimmerman, Paul Weir Co. (2) 